\title{
Moda Sektöründe Transmedya Hikâye Anlatımı: Barbie Bebek Transmedya Uygulamaları Örneği
}

\author{
Süheyla Bayraktar (Öğr. Gör.) \\ Kocaeli Üniversitesi Gölcük Meslek Yüksekokulu \\ sbayraktar@kocaeli.edu.tr
}

Başvuru Tarihi: 15.03.2018

Yayına Kabul Tarihi: 21.06.2018

Yayınlanma Tarihi: 30.07.2018

\section{Öz}

1950'li yıllardan bu yana küresel olarak en fazla bilinirliğe ve satış oranına sahip olan oyuncaklardan biri olarak Barbie bebekler bir oyuncak markası olmanın yanı sıra giyim biçimi, kullanılan aksesuarlar ve ortaya koydukları ideal vücut ölçüleri ile modern kadın için bir rol model oluşturmuştur. Bu yönüyle Barbie bebeklerin bir tüketim nesnesi olarak modanın kitlelere benimsetilmesinde araç olarak konumlandırıldığını söylemek mümkündür.

Günümüzde yeni medya ortamları aracılığıyla daha çok sayıda medya platformuna açılan transmedya hikâye anlatıcılığı Barbie bebeklerin modayla ilgili uygulamalarının interaktif olarak kullanıcılara ulaşmasını ve hikâye evreninin genişlemesini sağlamaktadır. Kullanıcılar söz konusu uygulamalar sayesinde moda alanındaki yaklaşımlarını kendi yarattıkları kombinlere aktarmakta ve aynı zamanda kendilerine sunulan giysilerle günün modasını takip etme olanağı elde etmektedirler.

$\mathrm{Bu}$ araștırmanın konusu Barbie bebeklerin bir oyuncak figürü olmanın ötesinde moda sektörüyle olan ilişkisini transmedyal anlatı stratejileri temelinde ortaya koyarak tartışmaktır. Bu temel amaç doğrultusunda markaların pazarlama çalışmaları ekseninde transmedya hikâye anlatımının yeri ve uygulanma biçimi ile moda sektöründe Barbie bebeklerin işlevleri ve idealize edilmiş güzelliğinin taşıdığı sembolik anlamlar sosyal göstergebilimsel çözümleme yöntemi ile analiz edilmiş, çalışma bulguları betimsel olarak açıklanmıştır.

Anahtar Kelimeler: Moda, Transmedya, Hikaye, Yeni medya, Barbie Bebek, Marka. 


\title{
Transmedia Storytelling in Fashion Industry: A Sample of Transmedia Applications of Barbie Fashion Dolls
}

\author{
Süheyla Bayraktar (Lect.) \\ Kocaeli University Gölcük Vocational School \\ sbayraktar@kocaeli.edu.tr
}

Date Received: 15.03.2018

Date Accepted: 21.06.2018

Date Published: 30.07.2018

\section{Abstract}

As one of the most globally recognized toys in the world since the 1950's, Barbie e dolls have become a toy brand, as well as a role model for modern women with their clothing style, accessories and ideal body measurements. In this sense, it is possible to say that Barbie e dolls are positioned as vehicles as a consumer object of the fashion

Transmedia storytelling, which is now open to more media platforms via new media environments, enables Barbie e dolls to interactively access their fashion-related applications to users and expand the story universe. With these applications, users are able to transfer their approach in fashion to combos they create and at the same time get the opportunity to follow their fashion with the clothes offered to them.

The theme of this research is not only to be a toy figure of Barbie dolls, but also to discuss the relationship with the fashion sector and the feature of being the bearer of fashion. In line with this main objective, the functions of Barbie dolls in the fashion sector has been analyzed with the location and application style of transmedia storytelling in the axis of marketing activities of brands. In addition that the symbolic meanings of Barbie dolls' functions and their idealized beauty are analyzed by social semiotics analysis method, the study findings are descriptively explained.

Keywords: Fashion, Transmedia, Storytelling, New Media, Barbie Dolls, Brand. 


\section{Giriş}

14. yüzyıl sonlarında hayatımıza girmiş olan moda 20. yüzyılın ortalarında yaygınlık kazanmıștır. Bu zamana kadar genellikle lüks, sosyal statü ve varsıllıkla birlikte anılan modanın hem üretim olanakları hem de iletişim zorlukları nedeni ile geniş kitlelere tanıtılması söz konusu değildir. Modanın günümüze taşınmasında ve yaygınlık kazanmasında önce matbaanın icadı daha sonrada iletişim alanındaki gelişmeler sonucu ortaya çıkan farklı medyaların etkisi söz konusudur. Ancak 15. yüzyılın sonuna doğru, giydirilip çıkarılabilen elbiseleri ile günümüzdeki Barbie bebeklerin öncülleri sayabileceğimiz, yetişkin insan oranlarında üretilen bebekler mankenbebek işlevi görmekte ve moda ürünlerin sunumunda kullanılmaktaydı. Bu bebekler ileriki yüzyıllarda da Fransız modasını bütün Avrupa'ya taşıdılar. 20. yüzyılda bu görevi idealize edilmiş kadın güzelliği ile Barbie bebekler üstlendi. Barbie 1959'da fashion doll olarak üretilmiştir. Yaradılışından gelen doğasıyla Barbie çocuklara ve yetişkinlere giyim zevkini aşılamada ve son moda ürünlerin benimsetilmesinde etkin bir role sahip olmuştur. Birçok çocuğun moda ile ilk tanışması Barbie etiketli ürünler ile olmuştur. Diğer yandan dünyaca ünlü birçok moda evi hem Barbie için kreasyonlar yaratmış hem de Barbie giyim tarzından ilham almıştır. Özellikle çocuklarda tüketim alışkanlığı ve yeme-içme bozukluğu yarattığı savıyla birçok bakımdan aileler, basın ve akademik çevreler tarafından eleştirilse de o her zaman şık ve zariftir.

Barbie'nin moda ile olan ilişkisi yalnızca giysiler üzerinden olmamıștır. Barbie yaşamımıza yayılan birbiriyle ilgili birçok ürünüyle hem çocukların hem de yetişkinlerin dünyasını istila etmiştir. Barbie'nin hayat tarzı, onun hikâyeleri bu ürünler üzerinden anlatılmakta ve Barbie, ürünlerinin reklamı, tanıtımı ve dağıtımı çeşitli mecralar üzerinden yapılmaktadır.

Bu çalışma Barbie ürünleri ve Barbie'nin moda ile olan ilişkisini transmedyal anlatı stratejileri temelinde açıklamaya çalışmış, Barbi'nin idealize edilmiş güzelliğinin taşıdığı sembolik anlamları sosyal göstergebilimsel çözümleme yöntemi ile analiz etmiştir. Bu amaçla çalışma moda kavramı, modanın taşıyıcısı olarak moda medyası, oyuncak bebekler, transmedya hikaye anlatımı kavramı, transmedya uygulamaları ve Barbie transmedya uygulamaları biçiminde yapılandırılmıştır. Çalışmaya ait bulgular betimsel olarak açıklanmıştır.

\section{Moda ve Kavramsal Arka Planı}

Moda daha çok giyime eklemlenmiş olmakla birlikte birçok alandaki yenilik, farklılık, caziplik, estetiklik, lüks gibi bileşenleri de içerisinde barındıran muğlak bir kavramdır. Belli bir zaman diliminde genel beğeninin bir ifadesi olan "moda" Türk Dil Kurumu'nun online sözlügü tarafından şöyle tanımlamaktadır: “(moda) 1. Değişiklik gereksinimi veya süslenme özentisiyle toplum yaşamına giren geçici yenilik. 2. Belirli bir süre etkin olan toplumsal beğeni, bir şeye karşı gösterilen așırı düşkünlük" (www.tdk.gov.tr, Erişim: 01.02.2016).

Kökeni Latince "yapmak" anlamına gelen facito kelimesine dayanan "Moda" (fashion) terimi, zaman içinde, uyumluluk ve toplumsal ilişkiler, başkaldırı ve eksantriklik, toplumsal beklenti ve statü, baştan çlkarma ve aldatma gibi bir dizi değer ve kavramı ifade eder hale gelmiștir (Fogg, 2014, 8). Tarih boyunca farklı yan anlamlar yüklendiği için moda sözcüğünün tam bir tanımını yapmak zordur; sözcüğün anlamı ve önemi farklı toplumsal yapılardaki insanların giyim alışkanlıklarına ve adetlerine uygun olarak değișmiştir (Kawamura, 2016, 21). 
Moda, insanların değişiklik arayışı ve yeni biçimler yaratma duygusu ile oluşmakta, belirli zaman içerisinde çok çeşitli alanlarda meydana gelmekte ve kitleler tarafından benimsenmektedir. Bu nedenle sosyal grupların büyük çoğunluğu tarafından belirli süreler için benimsenen bir davranış biçimi halini almaktadır. Dolayısı ile moda o zaman dilimi içerisindeki toplum yapısının gelenek ve olaylarını yansıtmaktadır (Ünal, 2014,79).

Moda aynı zamanda çok büyük uluslararası bir iş gücünün çalıştığı milyarlarca dolarlık küresel bir endüstridir. Aslında, hammadde üretiminden başlayıp, couture (özel dikim) balo elbiselerinden jean pantolonlara uzanan geniş bir tarz yelpazesinde gerçekleştirilen üretim, dağıtım ve pazarlama etkinliklerini kapsayan bir sistem olan modadan, bir endüstriler ağı olarak söz etmek daha doğru olacaktır (Fogg, 2014, 7).

Moda, etki alanı, yenilik arayışı, iletişim gücü, taşıdığı anlamlar ve bunun toplumsal etkileri ile çeşitli biçimlerde ifade edilmiştir.

Hoskins'e $(2014,23)$ göre moda; "giyimin ve görünümün insanlar tarafından benimsenen değişken tarzlarıdır". Kratz ve Reimer'e göre ise moda anlam ve sembollerle doludur ve insanlar moda yoluyla, görsel olarak, birbirleriyle hızlı ve direk olarak iletişim kurabilirler. Moda insanlara, kullanmış oldukları giysiler yoluyla, kendilerini ve kimliklerini ifade etme olanağı sağlar; moda bireylerin kim olmak istedikleri, hangi sosyal gruba ait oldukları ve en çokta kimlerle ilişkili olmak istemediklerinin görsel bir ifadesidir. Daha da fazlası, Bennett modanın bireyin kendi kimliği hakkında en hızlı fikir verecek kanallardan biri olduğunu ve insanların kendilerini kelimelerin ötesinde, elbise ile ifade edeceğini belirtmiştir (Noh, 2015, 3). Craine $(2013,11)$, giyimin tüketim ve kimlikle olan ilişkisini, "giyim, tüketimin en görünür biçimlerinden biri olarak, kimliğin kurulmasında önemli rol oynar" cümlesi ile açıklar.

Fred Davis, modanın istikrarsızlık ve kararsızlıktan beslendiğine vurgu yapar. Modanın bu istikrarsızlıklardan beslenerek tekrar tekrar kendini yarattığına dair ifadesi şöyledir:

Toplumsal ve teknolojik değişimin, yaşam evrimindeki biyolojik eksilmelerin, ütopik düşlerin, zaman zaman yaşanan felaketlerin etkisiyle sonsuz bir biçimleniş içinde olan kimliklerimiz, içimizde sayısız gerilim, paradoks, kararsızlık ve çatışma doğurur. İște moda da, kolektif düzeyde yaşanan, tarihte bazen tekerrür eden bu kimlik istikrarsızlığından beslenir (Davis, 1997, 28-29).

George Simmel ise modanın çatışmacı tarafına vurgu yapar ve modanın bireylerin hem aynılaşma hem de farklılaşma isteklerine denk düştüğünü şu şekilde ifade eder:

Moda, verili bir örüntünün taklididir, bu nedenle de toplumsal uyarlanma yönündeki ihtiyacı karşılar; bireyi herkesin yürüdüğü yoldan ilerlemeye sevk eder; her ferdin davranışını salt örnek haline getiren genel bir durum ortaya koyar. Aynı zamanda, ayırt edilme ihtiyacını, farklılaşma, değișim ve bireysel aykırılık eğilimini de aynı ölçüde tatmin eder. Moda toplumsal eşitlenme eğilimi ile bireysel farklılaşma ve değișim eğilimini tek bir eylemde birleştirmemizi sağlayan çok sayıdaki hayat formunun özgül bir örneğinden başka bir şey değildir (Simmel, 2006, 106).

Whatson $(2007,7)$, modanın kapsayıcılığına ve zamanla olan ilișkisine değinir; modanın ifade ettiği şey, etek boyundan, siluetlerden ve renklerden çok daha derindir. Moda, yemekten özel sanat tutumlarına, müzikten sekse dek, her şeydeki ruhsal değișiklik ve toplumsal alışkanlıklarla yarıșır. Sadece en büyüleyici ve 
etkileyici eğlence biçimlerinden biri olmakla kalmaz, aynı zamanda, zamanın en şaşmaz göstergesidir.

Barthes ise modanın iletişim yönüne dikkat çeker. Barthes, Saussure'un dil üzerine yaptığı çalışmalardan yola çıkarak modanın bir göstergeler sistemi ve bir anlatım dili olduğunu ifade eder. Sassure çalışmalarında dili "langue/dil" ve "parole/söz" olmak üzere ikili bir ayrımla inceler. "Langage/dil" ise hem dili hem de sözü kapsayan genel bir kavramdır. Dil bir değerler dizgesidir ve bireyden bağımsız toplumsal bir kurumdur. Söz ise bireyseldir ve birey tarafından gerçekleștirilir. Barthes $(2013,8)$, bu yapıyı giysi dizgelerine uyarlayarak tıpkı dilde olduğu gibi bireyin kişisel giyim zevkinin yanı sıra (parole) kişiden bağımsız kurumsal kimlik, sosyal temel, gerçeklik gibi genel dizilimlerine (langue) dikkat çeker.

Moda genel olarak yenilik, gelip geçicilik ve değişiklik ihtiyacı ile ilişkilendirilmiş, sembolik değerleri de içerisinde barındıran kültürel refaranslara bağlı bir fenomen olarak ifade edilmektedir. Ancak moda hem sembolik bir sistem hem de maddi kültürdür. Moda emtia ürünleri satar ve ticari sistemin bir ürünüdür (www. annekesmelik.nl, Erişim: 29.07.2017).

Moda sahip olduğu potansiyel ile dünyanın en önemli endüstrilerinden biridir ve küresel ekonominin en önemli itici güçlerinin önemli bir parçasıdır (https:// images.businessoffashion.com, Erişim: 29.07.2017). Bu anlam içerisinde moda "bir yandan biçim, malzeme ve renkleri, diğer yandan konum, meşguliyet, durum ve mizaçları; daha basit ifade edersek, bir yanda giysileri, diğer yandan dünyayı sonsuzca düzenleyen bir bileșimin varyasyonlarıdır" (Waquet ve Laporte, 2011, 8).

\section{Moda Medyası ve Oyuncak Bebekler}

Çoğu araştırmacı Batı̀da kurumsallaşmış bir moda döngüsünün başlangıcı olarak XIV. yüzyılı (Davis, 1997, 28) kabul etse de modanın medya ile geniş kitlelere tanışması sonraki yüzyıllara kalır. Yeni giysilerin, yeni renklerin, yeni biçimlerin ve aksesuarların yayılması, grafik enformasyonların malzemesi olarak kâğıdın yayılmasından yüzyıllar içerisinde adım adım yararlanılmıştır. Hiyerogliflerin malzemesi olan papirüs ya da tezhipçiliğin malzemesi olan parşömen eski toplulukların giyim kodlarını günümüze taşımıştır. Ancak giyim kuşamın 1450'den itibaren iradi ya da tesadüfi olarak günümüze taşınmasında başat rol matbaanındır. Moda gravürleri, mektup yoluyla satış katalogları, moda gazeteleri, sonra da kadın dergileri çok sayıda aktarılmak ve satılmak için tasarlanıp dağıtılmıştır (Waquet ve Laporte, 2011, 18).

Sonraki yıllarda fotoğraf sanatının doğması (1830-1865), dikiş ve örgü makinelerinin icadı, Britanya endüstrisinin dünya ticaret merkezi haline gelmesi; ayrıca o yıllarda Fransa'nın da sanat ve kültürün merkezi haline gelmesi modayı etkilemiştir. 18701890 arasında ampulün ve telefonun icadı, 1889 yılında Vogue dergisinin yayın hayatına başlaması, şehir merkezlerinde büyük mağazaların açılması moda ve giyim sanayisinin gelişmesinde katkı sağlamıştır (Türker, 2017, 14).

Günümüzde moda çok boyutlu, çok kültürlü ancak ülkeler arasında giyim kültürünün birbirine benzediği bir endüstri haline gelmiştir. Genel moda trendlerinin yayılması ve benimsenmesi açısından medyanın büyük önemi vardır (Dal ve Gürpınar, 2010, 3740) Sinema ve televizyon gibi canlı imge malzemelerinin (Waquet ve Laporte,2011, 19) yanı sıra kişisel tarz blogları, trend şirketleri, internet medyası markaları ve üç 
yüz yıldır faaliyet gösteren basılı dergiler gibi bileşenlerden oluşan moda medyası, moda endüstrisinin iletişim aracıdır. Markalar ve tüketiciler arasında köprü işlevi görmekle birlikte, neyin moda olduğunu belirlemek konusunda son derece etkilidir (Hoskins, 2015, 79).

Moda sadece nesnel formlarda değil, imaj ve içerik olarak da var olmaktadır. Tasarımcılara ek olarak, belirli kıyafetlerin neyi ifade ediyor olabileceğini anlatan imge ve fikirler ortaya çıkaran ve etrafa yayan (moda fotoğrafçıları, gazeteciler ve hatta müze küratörleri gibi) başkaları da vardır (Fogg, 2014, 7). Yine moda nesnelerinin geniş kitlelere benimsetilmesinde moda dergileri, fotoğrafçlar, gazeteciler kadar toplumdaki kanaat önderlerinin de önemli bir payı olduğu söylenebilir. Giyim unsurlarının yenice sunulmuş biçimlerini moda olarak meșrulaștırmak kabul edilmelerini gerektiren bir basamaktır. Modaya uygun giysileri, onay etiketi daha düşük sosyal görünürlüğe sahip insanlarca önem taşıyan, tanınmış ve prestij sahibi kişiler aracılığı ile sunmaktır; ki bu yolla moda kabul edilir ve arzu edilir kılınır. Moda yayılımının etkili önderleri arasında krallar, kraliçeler, film yıldızları gibi pek çok farklı arka plan insanları bulunur (Kawamura, 2016, 123).

\section{Günümüzde Modanın Taşıyıcısı Olarak Barbie Bebekler}

Bebek yapımının ilk defa İ.Ö. İki binlerde Mısır'da başladığı, İ.S. 6. yüzyılda Yunan ve sonra da Roma'da devam ettiği ve geliştiği, ancak soyluların çocukları için ilk zanaat ürünü bebeklerin 15. yüzyılda ortaya çıktığı bilinmektedir. Bu yüzyılın sonuna doğru Fransa'da Fransız modasını tanıtmak amacıyla yetişkin insan oranlarında manken bebekler üretilmiştir. Bu bebekler, giydirilip çıkartılabilen elbiseleriyle bugünkü Barbie'nin atası kabul edilebilir (Akbulut, 2009, 183).

Malzeme örneklerinin eşlik ettiği eskizler aracılığıyla müşteriye yeni tarzlar sunulduğunda ya da tamamlanmış bir elbise üretildiğinde, onu ilk giyen canlı bir kadın olmaz, elbise önce bir tahta bebek üzerinde sergilenirdi. Gerçeğe uygun boyutlarda modeller akla gelmeden çok önce, moda bebekleri ya da onlara verilen isimle şapkacı mankenleri, yeni modalara dair bilgiyi yaymak için kullanılırdı. Moda bebeklerinin giysinin en son tarzlarının dolaşımında kullanılan en son araçlar olduğu kaydedilmiştir. Paris'te sergileme için günün modası ile giydirilmiş iki gerçek boyutlu mankenin kullanımı yaygın bir uygulamadır. "La Grand Pandora" modalar her değiștiğinde baştan aşağı donatılırdı. Bebeklerin en küçüğü, "La Petite Pandora" bile modaya uygun giysiler ile donatılırdı.1391 gibi erken bir tarihte (Fransız Kralı) 6. Charles, İngiltere kraliçesine onun ölçülerine göre yapılmış ve en son tarzlarla giydirilmiş gerçek boyutlu mankenler göndermişti (Kawamura, 2016, 134).

Rönesans'tan itibaren bebekler giydirilmek ve sunulmak için tasarlanmıştır. "1497 yılında, kraliyet tutanaklarında Anne de Bretagne'nin İspanya kraliçesine hediye etmek için kocaman bir bebek sipariş verdiği geçer. Kendine sunulan bebek gardırobundan hoşnutsuz kalan kraliçe bu gardırobu yeniden yaptırmıştır". Naiplik döneminden itibaren 18. yüzyıl boyunca, kadın kafalı ve kadın vücutlu bebekler, yeni giysileri bütün Avrupa'ya taşımak için genellikle de Fransa'da imal edilecektir (Waquet ve Laporte, 2011, 17). Fransız kralı 14. Louis, (1638-1715) Fransız modasının en iyisi olduğunun bilinmesi ve bunu diğer ülkelere kanıtlamak için bütün Avrupa ülkelerine son moda giysiler giydirilmiş oyuncak bebekler gönderilmesini emretmiştir. Soylu hanımlar bu muhteşem tasarımları anlata anlata 
bitirememiş ve beğendikleri elbiselerin terzileri tarafından yapılmasıyla zamanın modasını takip etmişlerdir (Daynes, 2007, 37).

Sonraki yıllarda manken-bebek işlevi gravürlerin yaygınlaşması ile son bulacaktır. Ama 19. ve 20. yüzyılda bebekler, küçük kızları eğlendirmeye yönelik olsalar bile, kendi dönemlerinin modasının taşıyıcılarıdırlar (Waquet ve Laporte, 2011, 17).

20 yüzyıl boyunca oyuncak üretimi sanayileșmiş ve uluslararasılaşmıştır (Ferguson, 2006, 2). Kitle üretiminden önce zengin çocuklar zarif gardıroplu oyuncak bebeklere sahipken sıradan çocuklar ev yapımı, kabaca dizayn edilmiş ve sıklıkla cinsiyetsiz oyuncak bebeklere sahiptir. İlk seri üretim bebekleri ise çocuğu anne rolüne teşvik eden, geleneksel rolleri güçlendirilmiş oyuncak bebeklerdi. Anneliğe teşvik etmesinden dolayı her iki tür oyuncak da doğru ve sağlıklı oyuncaklar olarak düşünülüyordu. Barbie, Amerikalılara oyun için yeni bir olanak sundu. Barbie, Amerikan çocuk kitlesi (the mass of American Children) için elde edilebilir, ilk fashion doll idi (modayı temsil eden ilk bebekti) (Scott, 2002, 153-154).

Ruth Handler'ın, kızının kâğıttan bebeklerle oynadığını ve bu bebeklere yetișkin rolleri verdiğini fark edip, oyuncak bebek Barbie'yi üretmeye başlamasının üzerinden tam 57 yıl geçti. 57 yıldır, 99-46-84 ölçüleriyle kusursuz ve doğaya aykırı bir güzellik algısı empoze eden Barbie bebekler, (https://vogue.com.tr, Erişim: 12.07.2017) 1959'da piyasaya çıktı ve bu tarih itibariyle makyaj malzemesi, kıyafet, çanta, kalem, kalem kutusu, abajur ve parfümler de dâhil akla gelebilecek her türlü ürün ve ürün kategorilerine imzasını atarak hayatın farklı alanlarına yayıldı (www. Barbieoyuncakbebek.com, Erişim: 12.07.2017).

Barbie, 20. Yüzyılın en başarılı oyuncaklarından biri olarak kabul edilmektedir. Dünyanın her yerinde en çok satan oyuncak olan Barbie'nin ylllık cirosu 1.9 trilyon dolardır (Uncu, www.academia.edu, Erişim: 04.12.2017). 1959 yılından bu yana Amerikan toplumunda kültürel bir ikon olarak konumlanan Barbie, yıllık gerçekleştirdiği yaklaşık bir milyar dolarlık satış ile oyuncak endüstrisi içerisindeki diğer kız bebekler arasında karşılaştırılamayacak bir üstünlüğe sahiptir ve her bir Amerikalı kız çocuğunun ortalama sekiz Barbie bebeği olduğu bilinmektedir (Tulinski, 2017, 4). Barbie bebekler kız çocukları için kendi kendilerine saatlerce sıkılmadan oynayabilecekleri bir oyuncak, arkadaş hatta rol model olmaktadır. Kı çocukları oyuncak bebeklerini diledikleri gibi giydirir, makyaj yapar, saçlarını boyar ve süslerler. Bu tarz bebeğe yönelik davranışlar, bazı araştırmalara göre küçük kızların annelik içgüdülerini geliştirir ve bazen güzeller güzeli bir prensese, bazen bir şarkıcıya bazense bir politikacıya dönüşen Barbie bebekler küçük kızların hayatlarının ileriki dönemlerinde hissedecekleri güzellik ve meslek algısını yönlendirerek onlara rol model olmaktadırlar (www.Barbieoyuncakbebek.com, Erişim: 12.07.2017).

Barbie'nin modern toplumdaki rolünü anlayabilmek için çok sayıda araştırmalar yapan, sosyoloji profesörü Mary Roger, yazdığı 'Barbie Kültürü' adlı kitapta, bu bebeğin sadece bir oyuncak olması dışında farklı temsillerinin de olduğunu belirterek, bebeği bir popüler kültür ikonu olarak tanımlamıștır (Uncu, www.academia.edu, Erişim: 04.12.2017).

Yeni teknolojik imkânlar bu bebeklerin tüketim kültürü içerisinde de aktif bir rol almasını sağlamıștır. 1950’lerin sonlarında televizyonun yaygınlaşması ve filmlerin 
başarısının yanı sıra özellikle taş bebekler olmak üzere giysi ve oyuncak pazarlarının büyümesi göze çarpan olaylardır. Bu dönemde bebek ve giysideki çocuk modasında görülen ilerleme tüketim mallarında ve ürünlerinde (kremler, șampuanlar, losyonlar) kaldıraç etkisi yaratmıştır (Simili ve Sauza, 2015, 203).

Barbie bebekler altmışların başındaki ilk örnekleri ile top modellerin yüksek moda imajlarını ve Paris couture giyimini temsil ediyordu. Fakat kısa bir süre sonra görüldü ki küçük kız çocukları daha çok bir kimlik edinmek için Barbie istiyorlar. Barbie, onu en iyi arkadaşı olarak gören bütün bir nesil kızların arkadaşı ve sırdaşı oldu. Aslında, o gençlerin hayal dünyasının kapısının açılmasına yardımcı oldu (http:// files.shareholder.com, Erişim: 29.07.2017).

Barbie'nin, giysi standartları, idealize edilmiş vücudu ve davranış kipleri (modes of behaviour) yoluyla çocuklara kadınlığın kodlarını öğrettiği söylenir. Barbie bebek ile oynayan kız çocukları başarılı ve popüler olmak için tıpkı Barbie bebek gibi bakımlı görünmek zorunda olduklarını öğrenirler. 0 katı ve ince, her zaman gülümseyen, tertemiz ve gösterişli ve çoğunlukla pembeler içerisindedir. Daha da önemlisi, bu modanın kendisi lüks ürünlere, makyaj yapmaya ve klyafet almaya dayanır (Toffoletti, 2007, 57-58).

1992'de, dünya çapında her iki dakikada bir Barbie bebeği satıldı (Piche, 2009, 6). Sadece 1992 yılında 1 milyar Dolar değerinde Barbie ve onun aksesuarları satıldı. 2001 'de ise bu rakam, haftada ortalama bir milyona ulaştı. Mattel, 2012 yılında 1,275 milyar Dolar; 2013 yılında 1,202 milyar Dolar ve 2014 yılında 1,009 milyar Dolar değerinde Barbie satışı yaptı fakat 2015'te, Barbie'nin satışlarında \%16’lık bir düşüş yaşandı. Time Dergisi, bu durumu "Mattel'in Emekli Barbie'yi çıkarma zamanı gelmiş olabilir." diyerek alaycı bir şekilde yorumladı. Time Dergisi'nde yer bulan bu yoruma göre; satışlardaki bu düşüş, satış stratejilerinin yanlışlığından kaynaklanmamaktadır. Artık 56 yaşında olan Barbie'nin hâlâ ulaşılması imkânsız vücut ölçüleri bu durumun nedenidir (Tatar, 2016, 169).

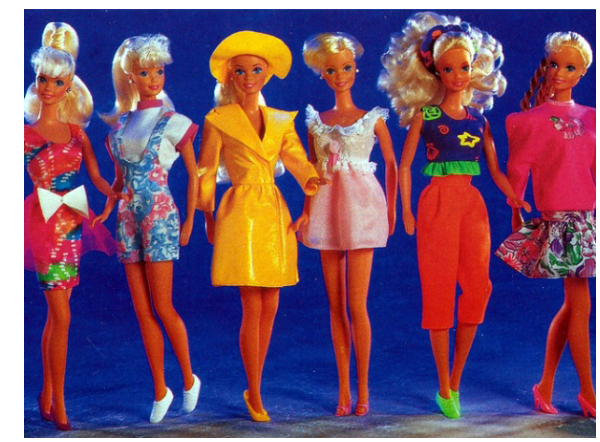

Şekil 1: Ídealize Edilmiş Bedenleriyle Barbie Bebekler Kaynak: www.Barbie eoyuncakbebek.com, Erişim:12.07.2017

$\mathrm{Bu}$ ikonik bebeğin bilinçli veya bilinçsiz dayatmış olduğu hiç değişmeyen fiziksel özelliği ve dayatmacı güzellik anlayışı yalnızca Time dergisinin değil akademik dünyanındatartışmakonularıarasındadır(https://vogue.com.tr,Erișim:12.07.2017). Bebeğin gerçekçi olmayan vücut oranları ve genç kızlar üzerindeki varsayılan zararlı etkileri birçok eleştiri ile karşılanmıştır (Drıessen, 2016). 11 inçlik bir bebeğin sadece çocuklarda değil kadın ve erkek yetişkinlerde bir etki yaratması şaşırtıcıdır. Birçok Barbie bebek araştırmacısının bebeğin üretim amaçlarına bakış açıları ya tamamen pozitif ya da negatiftir (Piche, 2009, 6). Akademik analizlerden popüler medya 
yorumlarına kadar değişen söylemler dünyanın en çok satan Barbie bebeklerinin sembolizmin geniş bir yelpazesinin tasavvuru olduğunu ifade etmektedirler. Barbie analistlerinin genel eğilimi, hedonist aptal bir tüketici, aşırı cazibeli bir aptal, boyun eğdirilmiş bir evcimen ya da tamamıyla bağımsız bir kadın olarak bebeğin sosyal sembol olarak abartılmasıdır. Bu tür söylemler, bebeğin sembolik anlamlarının asıl doğasını yakalamaktaki yetkin iddiaları karikatürize ederek, Barbie'nin çelişkili anlamlarına yoğunlaşmayı engellemektedir (Pearson ve Mullins, 1999, 225).

Yapılan çalışmalardaifade edildiği gibi bu bebekler ve diğer kültürel "idealler" örneğin top modeller, dansçılar ve basında yer alan kalıplaşmış vücut imajı göstergeleri yeme bozuklukları artışı ile de bağlantılı olmuştur (Norton vd.1996, 288). Mattel firması bu eleştirileri dikkate alarak Barbie 'nin hayatındaki sonsuz diyete, tek tipleşmeye son veren bir değişim gerçekleştirmiş ve Barbie balıketli, sarışın, esmer, uzun, kısa olmak üzere çok çeşitli ölçülerde üretilmiştir (www.radikal.com.tr. Erişim:01.02.2016).

Bir doğaçlama ikonudur Barbie, durum neyi gerektiriyorsa daima o olur... Kimilerinin savaş çlkartacak görüntüsü verdiğini kimilerininse özgürlükçü gördüğü Barbie bir tür çağdaş kişiliği temsil eder. Onunki, değişken, çok yönlü, etki yönetimli, davranışları durumdan duruma, rolden role değișerek söyleme bağlıdır. Barbie'nin kimliği köklerinde belirsizdir (Phillips, 2015, 221). Roger' göre (1999) Barbie’nin cinsiyet kimliği ve ait olduğu toplumsal sınıf kesin çizgilerle belirlenmemiştir ancak kullandığı aksesuarların yaşam tarzını yansıtması olarak Barbie'yi sadece tüketim için var olan bir statüye taşımaktadır. Vücudu ise plastik, samimi olmayan, sahte bir içtenlikte modern zaman metaforunun bir yansımasıdır (Uncu, www.academia.edu, Erişim: 04.12.2017).

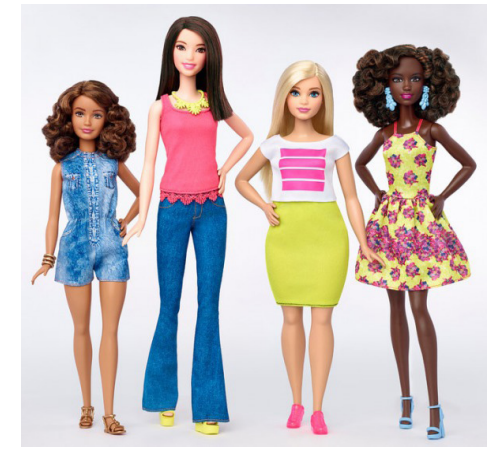

Sekil 2: Tabu Ylkan Barbie Bebekler

Kaynak: http://vogue.com.tr, Erişim:12.07.2017

\section{Medya Alanında Postmodernist Yaklaşımlar Ve Yöndeşme}

Postodernizm" teorik kaynağını Fransız post-strüktüralist akımından Jean-François Lyotard'ın 1979'da yazdığı 'postmodern durum' adlı kitabından alır. Kavram önceleri mimari ve sanatsal gelişmelerdeki deneysel hareketleri anlatmak için kullanılmıştır (Babacan, Onat, 2002, 12). "Modernizm" modern çağın sanat hareketleri olan (izlenimcilik, dışavurumculuk, gerçeküstücülük ve öbür avangard hareketler) betimlemek için kullanılırken "postmodernizm" modernizmden sonra gelen ve ondan kopan çeşitli estetik biçimleri ve pratikleri betimlemek için kullanılmıştır (Best, Kellner, 1998,17). Özetle bir çağ değişikliğini ya da modernlikten kopuşu ifade eden postmodernizm kendine özgü örgütleyici ilkelerle birçok kavramın bir arada tartışılmasına izin verir ve Boudrillard gibi Lyotard tarafından da postendüstriyel bir çağa yönelim olarak değerlendirilir. Baudrillard gerçekliğin bulanıklaştığı ve 
imgelerin egemen olduğu bu çağda üretici bir toplumsal düzenden yeniden üretici bir toplumsal düzene geçişte, yeni teknoloji ve enformasyon biçimlerinin merkezi bir rol oynadığını vurgular (Featherstone, 2013, 23).

Mc Luhan, yaklaşık kırk yıl önce teknolojik gelişmelerin iletişim ve etkileşim biçimlerini kökten değiştireceğini öngörerek ünlü "media is the mesage" deklarasyonuyla yalnızca içeriğin değil medyanın kendisinin de tüm yaşam biçimini dönüştürüp değiştireceğine dair bir perspektif ortaya koymuştur (Yanık, 2016, 898). Bugün ise yeni medyanın yükselişi ile ortaya çıkan bütünleşik yaklaşmalardan söz edilmektedir. Jan Van Dijk yeni medyanın en önemli yapısal özelliğinin telekomünikasyon, veri iletimi ve kitle iletişimini tek bir ortamda birleştirmesi olduğunu ifade eder ki bu yöndeşme (yakınsama) sürecidir. Bu yüzden de yeni medyaya daha çok mültimedya adı verilir (Dijk, 2014, 20). "Multimedya biçemselliğiyse, telekomünikasyon, veri iletimi, kitle iletişimi gibi iletişimin farklı boyutları ile imge, ses, metin ve sayısal veri gibi farklı veri türlerinin bir arada bulunmasıdır" (https://yenimedya.wordpress.com, Erişim: 13.06.2018 ). $\mathrm{Bu}$ bütünsellik ise transmedyal anlatımın en temel düzeydeki anlatımı için bir gerekliliktir. Transmedia öykü anlatımı bir modern dönem tanımlayıcı olan postmodernizm ile yakından ilişkilidir ve esas olarak yakınsama kültürünün bir sonucu olarak ortaya çıkmıştır (Gürel,Tığlı, 2014, 36).

\section{Transmedya Hikâye Anlatımı}

Hikâye anlatımı antik dönemden beri popülerdir, insanlar ateşin etrafına toplanarak şarkılar söyleyerek ve hikâyeler anlatarak eğlenirlerdi (Osipova, 2015, 6). Hikâyeleri eğlendirmek, ikna etmek ve açıklamak için anlatırız. Aklımız, tesadüfi olaylar ve nesnelerden hoşlanmadığından, başkalarından ayrılmak için yalıtılmış olaylar ve ögelerle kendi hikâyesini yaratır (http://videoturundus.ee, Erişim: 29.07.2017).

Hikâyeler unutulmaz. Ne kadar çok hatırlanırsa, büyük ihtimalle o kadar çok tekrarlanirlar (Mangold ve Faulds, 2009, 364). Burberry CEO'su Angela Ahrendts büyük markaların büyük hikâyeler anlatmak zorunda olduklarını ifade eder (Osipova, 2015, 6). Hikâye ile anlatılmış bir markanın insanlarla bağ kurabilmesinin en önemli sebeplerinden biri, hikâyenin markaya hayat vermesidir. Hikâye anlatımı, hedef kitleye giden yolda markaya bir kişilik, amaç ve her şeyden önemlisi hikâye aracılığı ile markayla bağ kurabilmiş kitleye bu hikâyenin bir parçası olma şansını verir (www.researchgate.net, Erişim: 29.07.2017).

Singh and Sonnenburg'a göre 21. yüzyıl markaları sanal alemde paylaşılan hikâyeler tarafından oluşturulur. Hikâyeler izleyicilerin beynine sorunsuzca girmenin gizli bir aracıdır ki bu film yapımcılarının kullandığı 25. kare ile karşılaştırılabilir. Marka literatürü önemli marka hikâyeleri ile tanınır çünkü marka sahipleri tarafından oluşturulan hikâyeler istikrarlı, tutarlı (coherent) ve beli bir iletişim stratejisini takip etmeye meyillidir (tend to follow), kullanıcı tarafından oluşturulan hikâye anlatımı tahmin edilemez ve büyük ihtimalle markaya tamamen farklı anlamlar yükler. Sonuç olarak, markanın itibarını korumak için marka sahipleri hem reaktif hem de özenli olmak zorundadırlar. Dijital medyanın yükselişi geleneksel hikâye anlatımını katılımcı hikâyeler ve onları yaratan kitleler arasındaki çok çeşitli bağlantılar ve daha güçlü yaratım için çoklu imkânlara sahip transmedya hikâye anlatımı stratejilerinin uygulamalarıyla canlandırdı ( Osipova, 2015, 6). 
Transmedya terimi özellikle, son yirmi yılda dünya üzerinde iletişim bilimcileri ve uygulayıcıları tarafından konuşulmaya başlanmıştır. Terimi ilk olarak 1991 yılında "transmedya metindaşlık" olarak kullanan Kaliforniya Üniversitesi Profesörü Marsha Kinder, gelişen medya sunuşları içerisinde öyküleme unsurları ve seyircinin ilgisi üzerinde durmuștur Transmedya Hikâyeciliği kavramını literatüre kazandıran Henry Jenkins ise terimi 2003 yılında makalesinde ve "Convergence Culture: Where Old and New Media Collide" adlı kitabında kullanmıștır. Jenkins'in "Transmedya Hikâyeciliği" tanımını kullanmasıyla birlikte hikâye anlatımının son yıllarda önem kazanan yeni medyayı da içerisinde barındıran yeni bir anlatı stratejisi ortaya çlkmıştır (Dönmez ve Güler, 2016, 156).

Jenkins vd. anlatımıyla; transmedyanın en temel düzeydeki anlatımı, "çoklu medya platformlarında anlatılan çok önemli hikâyelerin aynı anda mecralar arası akışıdır" Jenkins'e göre; her medya kendine düșenin en iyisini yapar. Böylece sinemada gösterilen bir film, televizyon, roman, çizgi roman da genişletilir ve bu filmin dünyası dijital oyunlar yoluyla keşfedilip deneyimlenebilir (Scolari a, 2009, 584). Jenkins'e göre çağdaş eserlerin birçoğu farklı medya (filmler, çizgi romanlar vb.) ve platformları (bloglar, forumlar, wikiler, sosyal ağlar) yoluyla kendi hikâyelerini çoğaltırlar (Scolari b, 2013, 2). Dolayısıyla transmedya hikâye anlatımının geleneksel tanımını "farklı platformlarda tercihen seyircinin katılımıyla anlatılan hikâyelerin, birbirni takip eden mecralar boyunca katılımcının haz alma duygusunu artırmasıdır" şekinde yapılabilir (http://videoturundus.ee, Erişim:29.07.2017).

Jenkins $(2016,19)$ birbirini takip eden hem geleneksel hem de yeni medya ortamlarının çarpıştığı, taban medyası ile kurumsal medyanın kesiştiği, medya yapımcısının ve medya üreticisinin güçlerinin beklenmedik şekilde etkileşime geçtiği anlatım mecralarını "yakınsama" kavramı üzerinden açıklar. Yakınsama, kimin konuştuğu, ne düşündüğü ve ne hakkında konuştuğuna bağlı olarak teknolojik, endüstriyel, kültürel ve sosyal değişiklikleri betimleyebilen bir kelimedir (http:// henryjenkins.org, Erişim:27.02.2018).

Yakınsama ile içeriğin çeşitli medya platformları akışını, çeşitli medya endüstrilerinin işbirliğini ve istedikleri türlü eğlence deneyimi arayışıyla neredeyse her yere gidebilecek medya izleyicilerinin göçebe davranışlarını ve bir anlamda kültürel alışverişi kasteder. Medya yakınlaşması dünyasında önemli her hikâye anlatılır, her marka satılır ve her tüketiciye çeşitli medya platformları üzerinden kur yapılır (Jenkins, 2016, 19-20) ve bunlar farklı anlatım stratejileri ile tüketici ile buluşturulur.

\section{Transmedyal Anlatı Stratejileri ve Özellikleri}

Transmedya hikaye anlatı stratejileri; Star Wars, Star Trek, Doctor Who ve The Hunger Games örneklerinde olduğu gibi aynı büyük hikaye dünyasında anlatılan çok sayıda anlatı (Franchise Transmedya Hikaye Anlatımı), birbirine bağlantılı medya platforları ile anlatılan tek bir anlatı (Portmanteau Transmedya Hikaye Anlatımı) veya her iki anlatıyıda içeren hibrit uygulamalar (Karma veya "Karmaşık Transmedya Öyküleme) (Cliff, 2017, 17-18) şeklindedir. Bu stratejilerin uygulanmasında sahip oldukları anlatım özellikleri Henry Jankins tarafından on madde ile açıklanmıştır. Bunlar;

1. Yayılabilme Özelliği; Transmedya öykü anlatımı, bir kurgunun bütün unsurlarının, birleştirilmiş ve eşgüdümlü bir eğlence deneyimi yaratmak amacıyla çoklu dağıtım 
kanallarına sistematik olarak dağılmış halde bulunduğu bir süreci temsil eder. Her medya platformu öyküye gelişimine kendine has özellikleri ile katkı sağlar. (http:// henryjenkins.org, Erişim:03.03.2018).

2. Bütünleşik Anlayış ve Sinerji; Transmedya hikaye anlatımı yarattığı sinerji ile medya sektörünün ekonomik yapısını güçlendirir. Modern medya şirketleri yatay olarak bütünleşiktir yani bir zamanlar farklı medya endüstrileri (geleneksel medya) olan bir dizi alanda çıkarları vardır. Büyük medya kuruluşları markalarını ve bayiliklerini olabildiğince çok farklı medya platformları üzerinden genişleterek ekonomik kazanç çabası içerisindedirler. Batman ve Süpermen filmlerinden çok daha önce basılı olan ve çizgi romanları buna örnek olarak gösterilebilir. Bu romanlar izleyicinin filmdeki deneyimini ve merakını arttıran bir arka plan öykü sağlar dolayısıyla pazarlama ve eğlence arasındaki çizgiyi bulanıklaştırmaya yardımcı olur (http://henryjenkins.org, Erişim:03.03.2018).

3. Kurgusal Bir Dünya; Transmedya hikâye anlatımı tek bir karakter üzerinden değil birbiriyle ilişkili karakterlerin kurgusal dünyalarına dayanır. Bu tarz anlatımdaki evren yaratma sürecinin hem yazarda hem de tüketicilerde ansiklopedik bir dürtüye yol açtığı söylenebilir. Farklı karakterle genişleyen ve bizim kavrayıșımızın ötesinde olan bir dünya sunarak klasik hikâye anlatımından farklılaşır (http://henryjenkins. org, Erişim:03.03.2018).

4. Uzantı (Eklenti) ; Uzantılar çeşitli işlevler sunabilir. Örneğin, BBC, neredeyse 10 yıl Doctor Who dizisine ilgiyi korumak için radyo dramalarını kullandı. Uzantı hikayenin tamamına ilgiyi artırırken bir bütün olarak kurguya gerçeklik duygusu katabilir veya bir seride gösterilen olaylar arasında köprü oluşturabilir (http:// henryjenkins.org, Erişim:03.03.2018).

5. Hikâyeye Farklı Giriş Noktaları; Transmedya hikaye uygulamaları farklı özelliklere sahip tüketiciler için farklı giriş noktaları yaratarak bir ürünün olası pazarını genişletebilir. Bu izleyicinin kendini rahat hissedeceği ve ilgi alanına yönelik uygulamalardır. Örneğin, gençler için Spider-man hikayesinin boya ve çizgi romanları düşünülürken yetişkin kadınlarının alternatif bir platforma olan video oyununa ilgisi așina oldukları Umutsuz Ev Kadınları oyunuyla sağlanmaya çalıșılır (http://henryjenkins.org, Erişim:03.03.2018).

6. Kolay Erişim; Hikâyenin her bir parçası, bir bütün olarak anlatı sistemine eşiz bir katkı sağlamak amacıyla, sunulduğu medya platformu bağlamında kolay erişilebilir ve kavranabilir olmalıdır (http://henryjenkins.org, Erişim:03.03.2018).

7. Öznellik ve İş birliği; Transmedya hikâye anlatımı farklı medya platformları arasında yüksek bir işbirliğini zorunlu kılar. Hikâyenin veya projenin farklı kanallara yayılımı genellikle tek bir sanatçı veya şirket tarafından gerçekleştirildiği ve işbirliği yapıldığı görülmektedir (http://henryjenkins.org, Erişim:03.03.2018).

8. İnteraktivite; Toplu zekâ terimiyle beraber anılan transmedya hikâye anlatımında hiç kimsenin tek başına bilemeyeceği düzeyde bir bilgi yayılımı söz konusudur. Katılımcılar, avcı ve toplayıcıdırlar. Verilen ipuçlarını değerlendirerek hikâyeyi çoğaltırlar (http://henryjenkins.org, Erişim:03.03.2018).

9. Performans; Transmedya hikâye anlatımı salt bilgi yaymaz, okuyucularının gündelikhayatlarınadadâhilolarakbirdizirolvehedefsağlar.Buboyutuyla, tüketicileri 
kurgu karakterler, kostümler vb. yoluyla kendi kurgusal dünyalarını oluşturma ve performe etme imkânı sunar (http://henryjenkins.org, Erişim:03.03.2018).

10. Süreklilik ve Boşlukları Doldurma; Transmedya metinlerinin ansiklopedik olma arzusu genellikle hikâyenin ortaya çıkmasında boşluk veya fazlalık olarak görülebilir: yani, tam olarak söylenemeyen ve hikâyeyi keşfetmek için daha fazla ipucu veren ekstra detaylar ortaya koyarlar. $\mathrm{Bu}$, parçaları birleştirme ve hikayeyle ilgili spekülasyonları giderme konusunda hayranlara güçlü bir motivasyon sağlar (http://henryjenkins.org, Erişim:03.03.2018).

Jenkins'in sınıflandırdığı bu transmedyal özellikler hikâye evrenin genişletilmesi ve tüketiciye benimsetilmesinde uygulanan stratejilerin sahip olması gereken özellikleri içerisinde barındırır. Uygulanan stratejiler tüketiciye farklı deneyim olanakları sunarken ürünlerin de kabul süreçlerini hızlandırır.

\section{Barbie Moda Bebekleri Franchise'nin Transmedyal Anlatım Özellikleri}

Popüler medya transmedya yoluyla günlük yaşamın her alanını işgal etmiştir. Popüler transmedya metinler arası olduğundan, ürünler arası okuma yapmayı zorunlu kılar. Örneğin; her bir Barbie bebek, DVD, tişört, ya da diş fırcası franchisedaki diğer her bir ürünle bağlantılıdır ve reklamlardan, filmlerden, kitaplardan ve video oyunlarından paylaşılmış temaların görselliğini kullanır. Bunun anlamı bir obje izole bir biçimde ele alınmamalı ancak bir küresel ağ içerisindeki ürünlerin çeşitliliği arasındaki eğilimler ve pazar geçmişleri gibi bağlantılarıyla birlikte araștırılmış olmalıdır (Wohlwend ve Peppler 2013, 130).

Barbie, devasa oyuncak üretimi, filmleri, video oyunları ve now apps'leri ile açıkça büyük bir big-businness franchise transmedyadır. Ancak her platform birbirinden tamamen bağımsızdır. Herhangi bir ürün Barbie Franchise'ının giriș noktası olabilir. Popüler www.Barbie.com, sitesi ile onun dünyasının bir parçası olmaya teşvik edilirsiniz. Sadece imzalayarak (sign up) otomatik olarak Barbie evrenin içine yerleştirilen bir karakter haline gelebilirsiniz. Barbie.com interaktiftir ve içeriklerin büyük çoğunluğu hayranlar tarafından oluşturulur (https://present. me, Erişim: 30.07.2017).

1959 yılında Mattel firması tarafından yaratılan Barbie'nin transmedyal özellikleri; yayılabilme (Spreadability), devamlılık ve çeşitlilik (Continuity vs. Multiplicity), derinlik ve genişlik (Immersion vs. Extractability), yeni bir dünya kurma (Word Building), serilik (Seriality), öznellik (Subjectivity), performans (Performance) olarak sıralanabilir. (https://transmediajournalism.org, Erişim:02.03.2018).

\section{Araştırmanın Amacı ve Yöntemi}

$\mathrm{Bu}$ araștırmanın konusu Barbie bebeklerin bir oyuncak figürü olmanın ötesinde moda sektörüyle olan ilişkisini transmedyal anlatı stratejileri temelinde ortaya koyarak tartışmaktır. $\mathrm{Bu}$ temel amaç doğrultusunda markaların pazarlama çalışmaları ekseninde transmedya hikâye anlatımının yeri ve uygulanma biçimi ile moda sektöründe Barbie bebeklerin işlevleri ve idealize edilmiş güzelliğinin taşıdığı sembolik anlamlar sosyal göstergebilimsel çözümleme yöntemi ile analiz edilmiş, çalışma bulguları betimsel olarak açıklanmıștır.

Çalışmada yararlanılmış olan görsel iletişimin sosyal göstergebilimi, imgelerle (ve diğer görsel iletişim araçlarıyla) ne söylenebildiği ve yapılabildiğinin, insanların 
imgeler aracılığı ile söylediklerinin ve yaptıklarının nasıl yorumlanabileceğinin göstergebilimsel kaynaklarının betimlenmesini kapsar (Jewitt, Oyama, 2007, 86). Bunu sağlamak içinse fotoğraflar, reklamlar, dergi sayfaları ve filmleri içeren çok çeşitli metinler kullanılır (https://pdfs.semanticscholar.org, Erişim: 07.06.2018).

\section{Barbie Moda Bebekleri (Fashion Doll) Transmedya Uygulamaları}

1. Yayılabilme Özelliği; Barbie 1959'dan beri farklı medya platformları üzerinden hayranları ile iletişim halindedir. Barbie'nin modayı benimsetmek için küçük hayranlarına ulaşabileceği en temel mecra internettir. Barbie internette hem kendi web sayfası olanaklarıyla hem de çeşitli hayran kitlelerinin oluşturmuş olduğu sosyal medya hesaplarıyla takip edilmektedir. Diğer yandan Barbie e-gazete dergi gibi ana akım medyayı ve bu medyaların internet uzantılarını da iletişim amaçlı kullanarak moda takipçileri ile yeni modellerini ve geçmiş dönemdeki ikonik giysi ve aksesuar modellerini paylaşmaktadır.

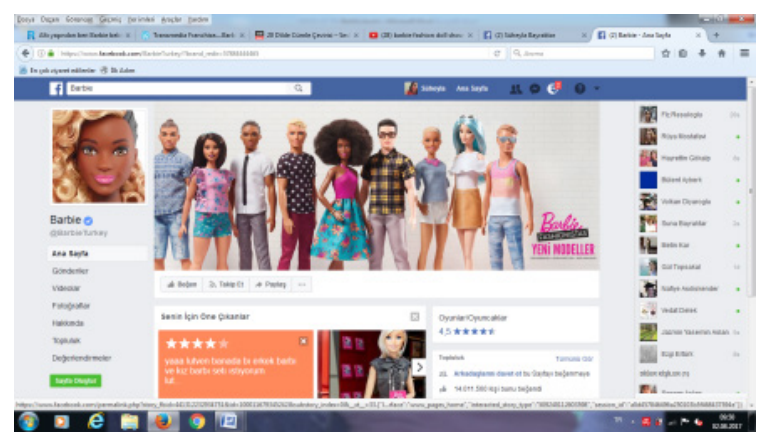

Şekil 3: Barbie'nin Sosyal Medya ve Diğer Medya Platformlarını Kullanım Örnekleri - Facebook Örneği

Barbie Youtube, facebook, twitter ve Pinterest gibi sosyal medya platformlarindan moda zevkini ve önerilerini izleyici ve tüketici kitle ile paylaşmaktadır. Diğer yandan Barbie hayranları çeşitli platformlar üzerinden Barbie'nin moda deneyimlerini takip edebilmekte ve paylaşımda bulunabilmektedirler. Örneğin Facebook'ta oluşturulan hayran hesapları (açık ve kapalı grup hesapları) buna örnek gösterilebilir

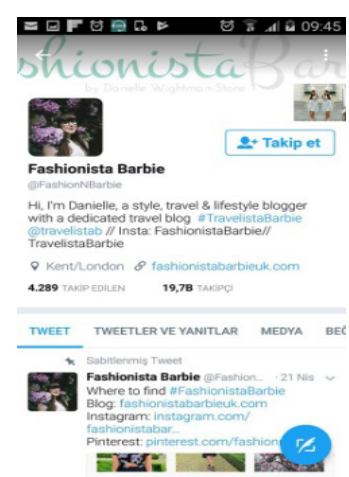

Şekil 4: Barbie

Twitter'da

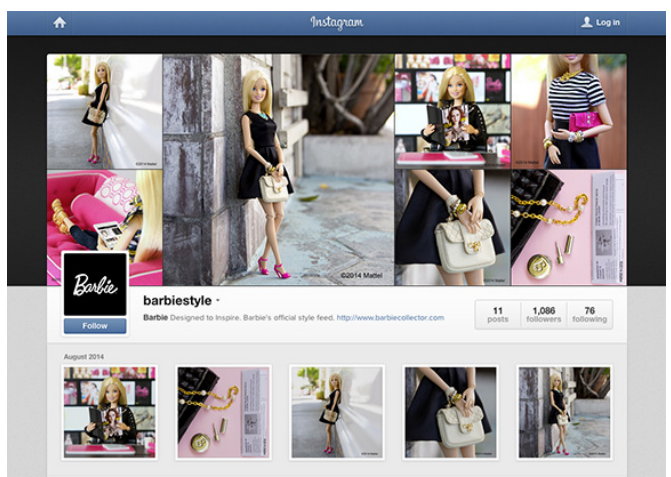

Şekil 5: Barbie İnstagram'da

Kaynak: www.google.com.tr, Erişim: 03.03.2018

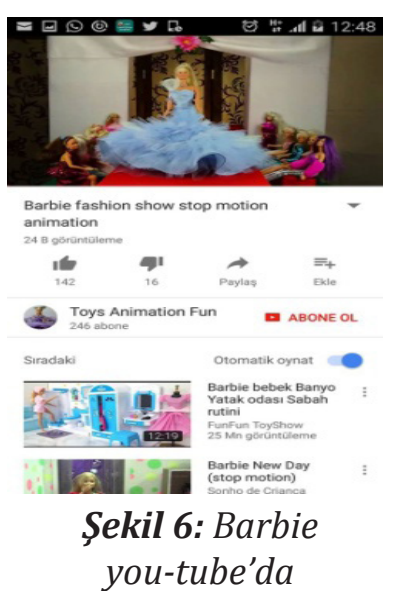

you-tube'da

Barbie Instagram hesabı @BarbieStyle'dan moda serüvenini, stil önerilerini, yeni projeleri, arkadaşları ve uluslararası seyahatlerini keyifli görselleri ile yayınlanmaktadır. 1959'dan beri kızların moda ikonu olan Barbie'nin Londra, Milan ve Paris'teki seyahatlerinin fotoğrafları bu insagram hesabından moda tutkunu takipçileri ile paylaşılmaktadır (www.barbieoyuncakbebek.com). 


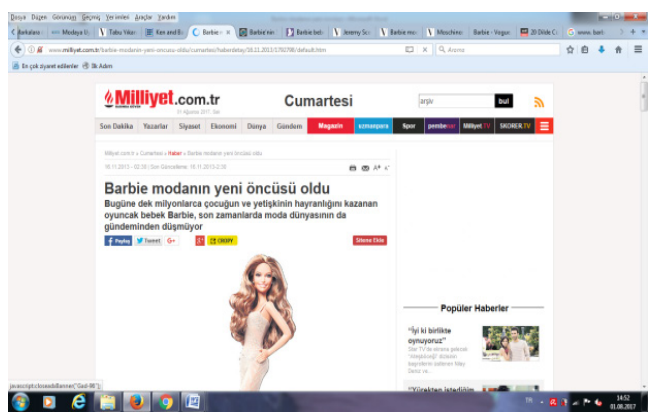

Şekil 7: Barbie Modanın Yeni Öncüsü Haberi

Kaynak: http://www.milliyet. com.tr, Erişim: 12.07.2017

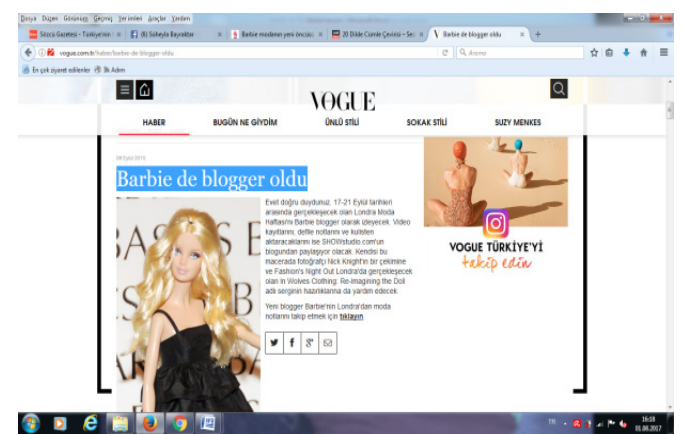

Sekil 8: Barbie de Blogre oldu

Kaynak: https://vogue.com.tr/haber/barbiede-blogger-oldu, Erişim: 12.07.2017)

Milliyet gazetesinde yer alan haber Barbie'nin moda trendlerini yakından takip etmesi, dijitalleşmesi ve sosyal medya popülerliği ile ilgilidir (www.milliyet.com.tr).

Barbie Blogger Oldu: Vogue dergisi Barbie'nin sosyal medya ve moda ile olan yakın ilişsisini aşağıdaki şekilde haberleștirmiştir.

Evet, doğru duydunuz. 17-21 Eylül tarihleri arasında gerçekleșecek olan Londra Moda Haftası'nı Barbie blogger olarak izleyecek. Video kayıtlarını, defile notlarını ve kulisten aktaracaklarını ise SHOW studio.com'un blogundan paylaşıyor olacak. Kendisi bu macerada fotoğrafçı Nick Knight'ın bir çekimine ve Fashion's Night Out Londra'da gerçekleşecek olan In Wolves Clothing: Re-Imagining the Doll adlı serginin hazırlıklarına da yardım edecek.

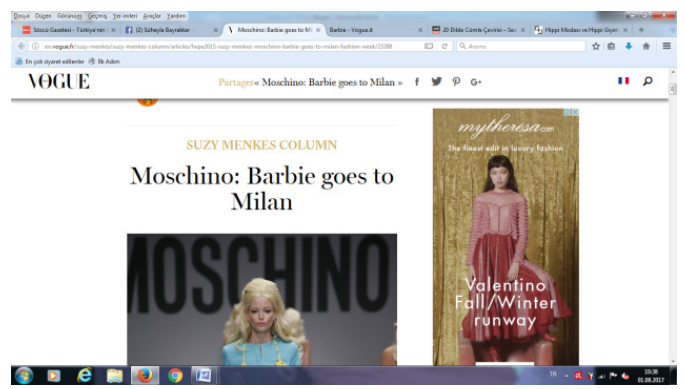

Sekil 9: Barbie E- Dergi Haberileri

Kaynak: www.vogue.it, Erișim: 14.06.2018

Moshino Barbie Goes To Milan haberi, ünlü moda dergisi Vogue'nun Milano Moda Haftasında Jeremy Scott'un Moshino markası için oluşturduğu Barbie koleksiyonu ile ilgilidir.
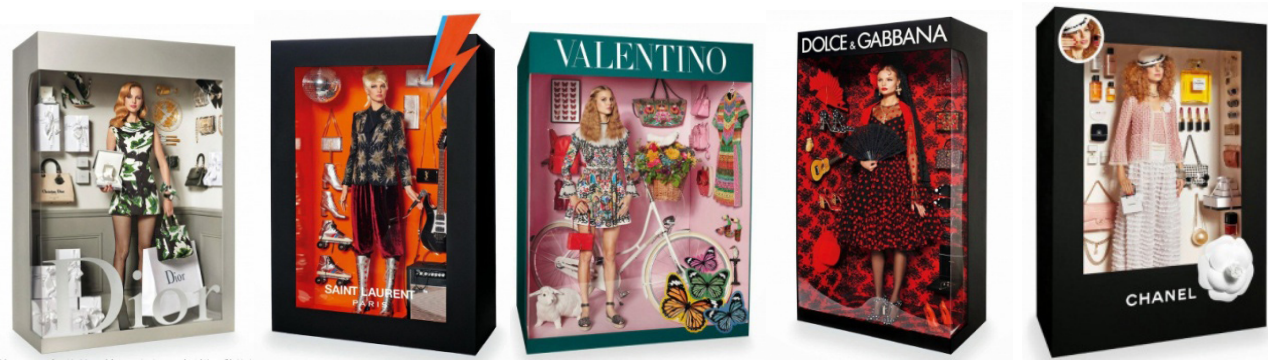

Şekil 10: Vogue Paris İçin Modeller Barbie Bebek Konseptinde Fotoğraflanmış Kaynak: https://bigumigu.com, Erişi; 14.06.2018

Moda dünyasına ilk adım çocuklarda genellikle oyuncak bebeklerin - özellikle Barbie ve türevi- kıyafetleri ve kombinasyonlarıla oluyor. Bu adımı göz önünde bulunduran 
fotoğrafçı Giampaolo Sgura da dünyanın en önemli moda dergilerinden biri olan Vogue Paris'in Aralık/ Ocak 2015 sayısı için ilham verici bir fotoğraf serisi ortaya çıkarmıştır. Magdalena Frackowiak and Elisabeth Erm, fotoğrafçı Giampaolo Sgura tarafından, temsil ettikleri en ünlü moda markalarının tipik giysileri içinde ve tüm gerekli aksesuarla donatılmış halde, tıpatıp kutularının içinde duran oyuncak bebekler gibi fotoğraflanmıştır. Bu serilerde Yves Saint Laurent, Louis Vuitton ve Gucci de dâhil olmak üzere, en ünlü Haute Couture mağazalarının modası sergilenmiştir (http://bigumigu.com)

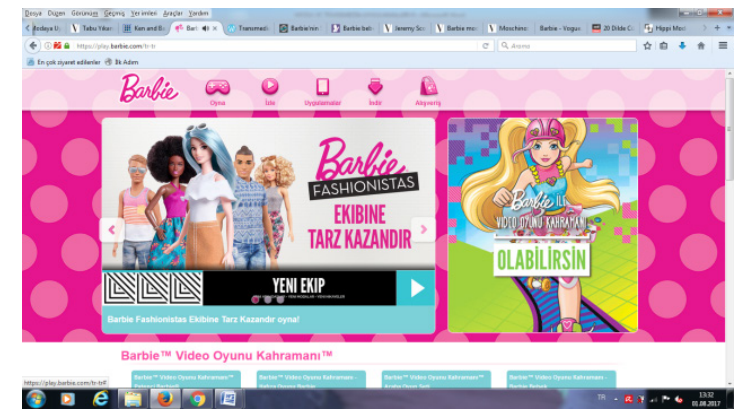

Sekil 11: Barbie e Fashiontas Ekibine Tarz Kazandır Oyunu Kaynak: https://play.Barbie e.com/tr-tr, Erişim:12.07.2017

Sayfadan ulaşılabilen "Barbie Fashiontas Ekibine Tarz Kazandır" oyunu moda meraklısı çocuklara yeni kombinler yapma olanağı sağlamaktadır. Barbie web sitesi oyna, izle, alışveriş ve uygulamalar butonları ile internetten çocuklara oyun oynama olanağı sağlarken alışverişlerini nereden yapacaklarına kılavuzluk etmenin yanı sıra çeşitli Barbie filmleri izleme olanağı sunmaktadır. Diğer yandan izle butonu birçok oyunuyla birlikte yeni Fashionstas Barbie bebeklerini izleme olanağı sunmaktadır. İndir butonu ise yazılabilir ögeler ve duvar kâğıtlarını indirme olanağı sağlamaktadır.

Barbie fashion doll geleneksel ve sosyal medyanın yanı sıra çeşitli kültürel etkinliklerin de konusu olmakta ve aşağıdaki gibi haberleştirilmektedir.

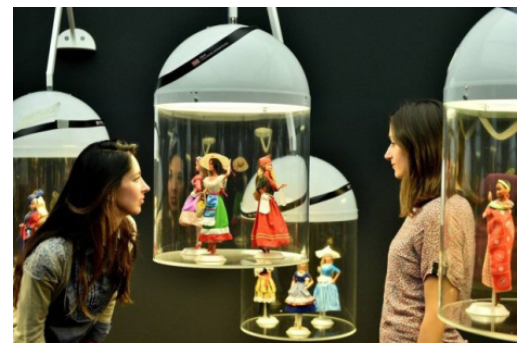

Şekil 12: Barbie Müzede Sergileniyor

Barbie "The Icon" kitabının yazarı Massimiliano Capella'nın

küratörlüğünde Roma'da Complesso del Vittoriano Müzesi’nde Barbie 'The Icon' sergisi ile hayranlarına sunuluyor.

Kaynak: www.turizmglobal.com, Erişim: 01.08.2017

Gardırobu için her yıl ayrı ayrı tasarlanan ve dikilen birbirinden şık kıyafetler ile genç kızlara stil oluşturmanın yollarını gösteren, kısa zamanda zevk ve moda anlayışını değiştirerek her tür dilsel, kültürel, sosyal ve antropolojik engeli aşmayı başararak global bir simge haline gelen Barbie Bebek, artık meraklıları için müzede sergilenmektedir (www.turizmglobal.com, Erişim: 01.08.2017). 
2. Devamlılık ve Çeşitlilik; İlk modeli manken olan Barbie zaman içerisindeki yolculuğuna birbirinden farklı çeşitli meslekler ve misyonlar edinerek devam etmiştir. Birbirini takip eden birçok hikâye ve role sahiptir. Bu bağlamda Barbie kendisini rol model olarak alan çocuklara hem meslekler hakkında fikir vermiş hem de moda dünyasına giyimin kodlarını meslekler ve başından geçen birçok hikâye üzerinden de taşımaya devam etmiştir.
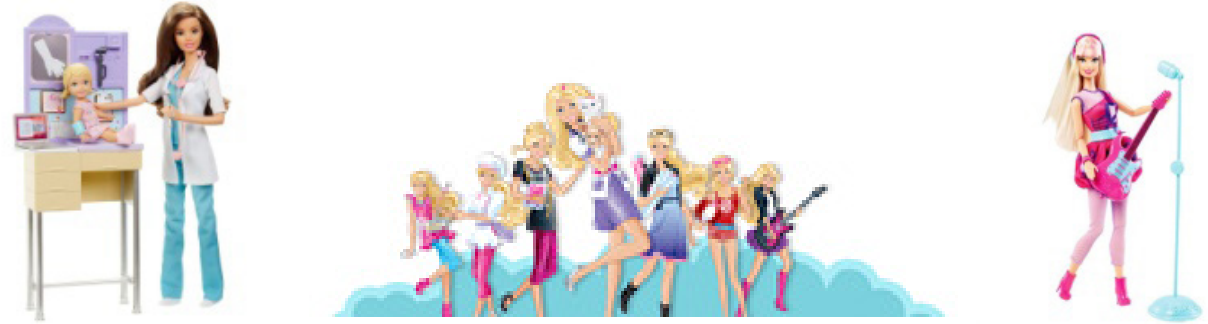

Sekil 13: Farklı Meslek Gruplarından Barbie Örnekleri Kaynak: https://play.Barbie e.com/tr, Erişim:12.07.2017

3. Derinlik ve Genişlik; Barbie ürünleri dijital ve geleneksel olmaküzere farklı medya platformları üzerinden dağıtılır. Barbie moda bebekleri aynı anda hem bir moda dergisinde hem bir boyama kitabında hem de bir dijital oyunda yer alabilmektedir. Diğer yandan, Barbie, kimliğini yansıtan birçok ürün kategorisine ve çeşitliliğine sahiptir. Bu ürünlerin derinlik ve genişliği, ürünlerin Barbie kullanıcılarının farklı yaşam alanlarında yer almasını ve farklı deneyimler edinmesini sağlamaktadır.
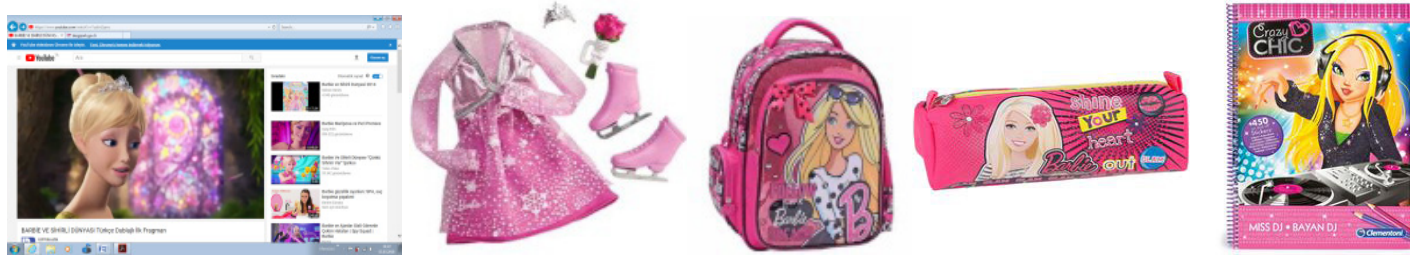

Şekil 14: Çeșitli Barbie Ürünleri

Kaynak: www.locopoco.com, Erişim:12.07.2017

4. Kurgusal Bir Dünya; Üretiminden günümüze kadar Barbie bebek serisine birçok karakter eklenerek hikâye evreni genişletilmekte, yeni karakterlerin Barbie'nin yaşamına getireceği yeniliklerle hayranlarının ilgisi canlı tutulmaktadır.
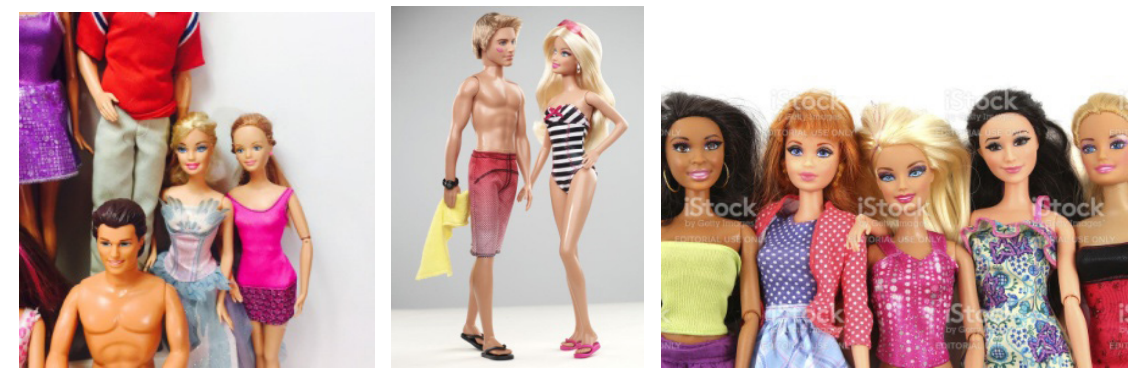

Şekil 15: Farklı Yașam Tarzları ve Hikâyelerine Göre Barbie Örnekleri Kaynak: www.google.com.tr, Erişim: 03.03.2018

5. Interaktivite; Barbie moda ile ilgili birçok hikâye, boyama ve giydirme kitapları yanı sıra çocuklar ile etkileşimde bulunabilen interaktif oyunlar ve oyuncaklar ile onların kendi yaratıcılıklarını kullanarak hayal dünyalarını zenginleştirmelerine ve yaratıcı potansiyellerini ortaya çıkarmalarına olanak sağlanmaktadır. Bu oyuncaklar internete bağlanma ve çocuklarla karşılıklı konuşma yetisine sahiptir. Çocuklar 
bu yolla hem giyim zevklerini geliştir hem de geleceğin moda takipçileri olmanın yolunda ilk adımlarını atarlar.

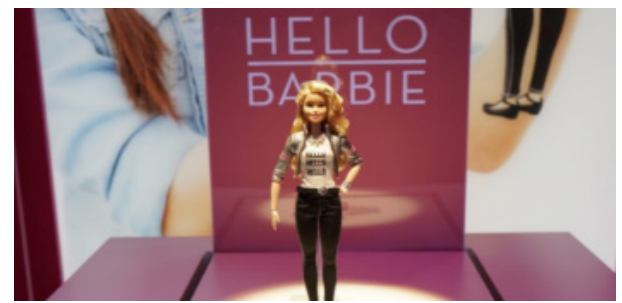

Şekil 16: Dünyanın ilk Etkileșimli bebeği Barbie Kaynak: https://bigumigu.com, Erişim : 03.03.2018

Oyuncak yapımcısı Mattel, Toy Talk ile güçlerini birleştirerek çocuklarla karşılıklı konuşabilen Hello Barbie'yi gelişstirme kararı almıştır. İnternet bağlantılı Barbie, Toy Talk tarafindan geliştirilen ses tanıma tekniği ile çocuklar ile interaktif iletişim kurma yeteneğine sahiptir. Mattel'in sözcüsü bu fikri oyuncă̆l kullanan kılardan aldıklarını, oyuncakla ilgili bir numaralı isteğin Barbie ile konuşabilmek olduğunu söylemektedir (http://her-an.org, Erişim:27.02.2018).

6. Serilik, Bütünleşik Anlayış ve Sinerji; Barbie ürünler birçoğu anlatılan hikâyenin farklı mecralardaki ifade biçimidir. Moda, Barbie ürünlerinin birçoğunun konusudur, modaya ilişkin bir anlatı bir boyama kitabının, bir hikâye kitabının, bir filmin konusu olduğu gibi bir oyunun konusu da olabilmektedir. Her biri farklı medyalarda tüketicilerine ulaştırılan bu ürünler yarattıkları sinerji ile hem ürüne ait hikâyenin çoğaltılmasına hem de bir diğer ürünlerin satışına katkı sağlamaktadır.
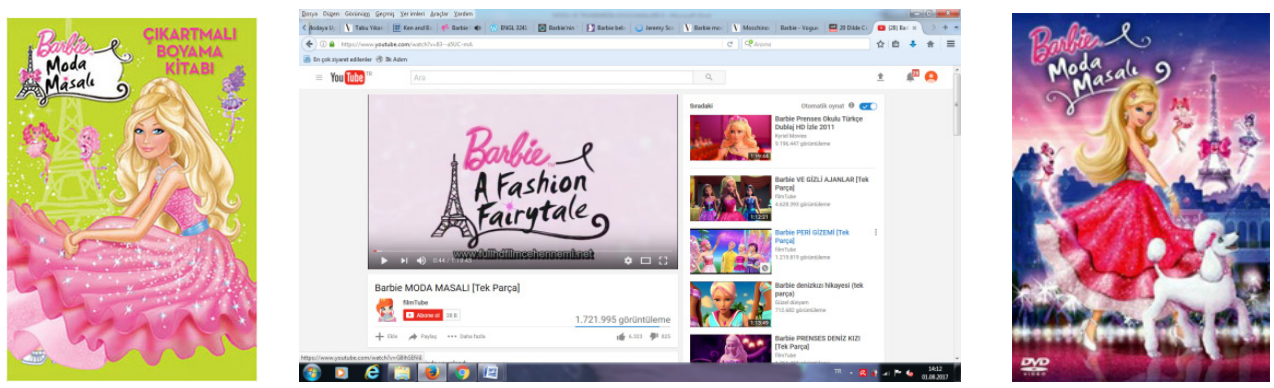

Şekil 17: Barbie Fashion Fairytale (Moda Masalı) Boyama, Hikâye Kitabı, Filmi ve Oyunu Kaynak: a) ve b) http://www.dr.com.tr, Erişim: 01.08.2017 c) http://www.idefix.com, Erişim :04.08.2017

Geleneksel ve elektronik medyadan sunulan ürünler birbirinin devamlılığını sağlamakta ve her mecra kendi olanaklarıyla hikâyeye katkı sağlamaktadır. Bu, ürünlerin bütünleșik bir anlayışıyla tanıtılmasına ve pazarlanmasına olanak sağlar. Çocuklar boyama kitabı, film ve masal kitabı olarak kendilerine sunulmuş olan "Barbie A Fashion Fairytale" (Barbie Moda masalı) adl hikayeyi birçok mecradan izleme olanağına sahiptirler. Çıkartmalı boyama kitabı; "Barbie Fashion Fairytale" ( Barbie Moda Masalı) adlı filmde yer alan görüntülere renk katmayı amaçlarken çocuklara giysileri istedikleri renkte boyayarak hem yaratıcılıklarını ortaya çıkarma hem de Barbie Fashion Doll'ün büyülü moda dünyasına girme olanağı sağlamaktadır.

7. Performans; Barbie'nin idealize edilmiş fiziksel özellikleri ve tarzı sıradan kişilerin yanı sıra Gigi Hagid, Kendall Jenner vb. (http://vogue.com.tr, Erişim:03.03.2018) gibi moda ve gösteri dünyasının birçok ünlü siması tarafından da performe edilmektedir. 


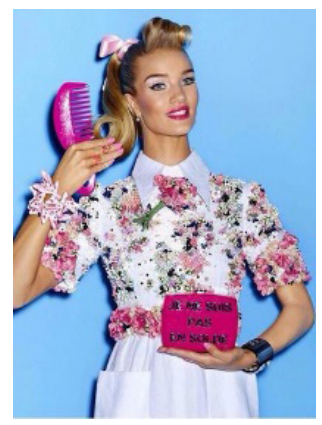

Şekil 18: Rosie Huntington-Whiteley Barbie oldu Kaynak: www.google.com.tr, .Erişim:03.03.2018

8. Öznellik: Barbie moda bebeklerinin, farklı medya ve organizasyonlar ile olan ilişkisi üreticisi olan Mattel firması tarafından yönetilmektedir. Böylece Barbie Modası daha geniş kitlelere ulaşmakta, grupların giyim, aksesuar ve diğer moda eşyalar hakkındaki beğenilerine etki edilmektedir.

\section{Barbie Moda Bebekleri (Fashion Doll) Sosyal Göstergebilimsel Analizi}

\section{Görsel 1}

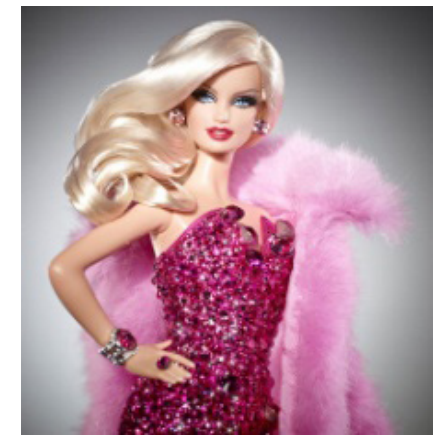

Görsel 1: Barbie İdeal Kadın

Kaynak: www.google.com.tr, Erișim:14.06.208

Fotoğraf renklidir ve Barbie plastik bebeğe aittir. Fotoğraf cepheden, sosyal bir ilişkiye yatkınlığı ifade eden orta plan bir çekimdir. Plastik bebek fotoğrafın merkezinde, sağ eli kalçasında, yüzü seyirciye dönük, koyu tonla çerçevelenmiş ve bağlamsızdır. Barbie, bordo parlak bir elbise ile fotoğraflanmıştır. Elbise, küpe, bileklik, yüzük ve sol omuza atılmış olan pembe yapay kürk ile kombin edilmiștir. Fotoğrafta bebeğin saçları özenle taranmış ve kürkle bir denge oluşturacak biçimde açıkta kalan omuzun üzerine bırakılmıştır. Cepheden çekilmiş fotoğraflar fotoğrafı çekilen kişinin cinsel gücünü ve onunla özdeşlenilebileceğini göstermektedir. Fotoğrafın koyu renk ile çerçevelenmesi ise merkezdeki objenin fark edilmesi ve izleyici üzerindeki etkisini artırmak açısından önem arz etmektedir.

Barbie bebek, üretim yeri olan Amerika'nın yaşam tarzına ait değerlerin aktarıcısı ve Amerikan güzellik anlayışının bir göstergesidir. Sarışın, uzun boylu, ince bedeni ile idealize edilmiş bu güzellik anlayışının temsilcisidir. Cepheden, orta plan çekilmiş olan fotoğrafi, moda giysileri ve bu giysileri sergileme biçimiyle plastik bir bebekten ziyade kimliği olan bir rol modeldir. Bakışları izleyicisine yönelmiş ve onlarla iletişim içerisindedir. Ayrıca Barbie'nin giysi ve aksesuarları zenginlik ve rahat bir yaşamın yanı sıra endüstriyel üretimin (yapay kürk ve mücevherler) göstergeleridir. 
Görsel 2-7

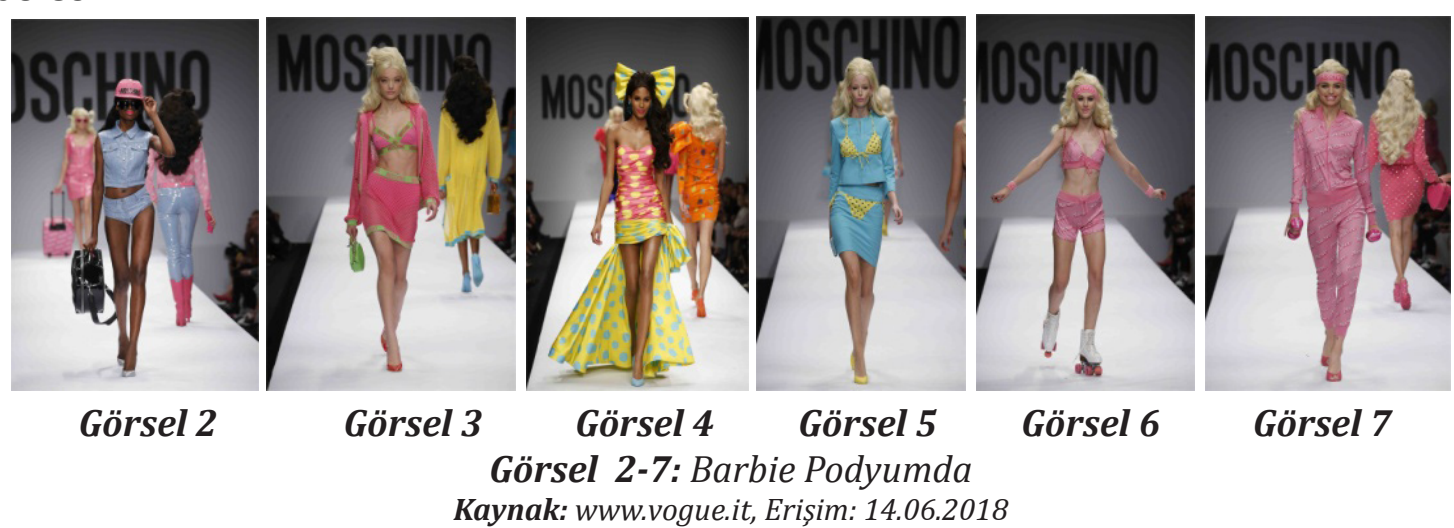

Fotoğraflar bir markanın giysi sunumunun görselleridir. Barbie her bir fotoğrafta farklı bir giyim tarzı ile farklı fiziksel özelliklere sahip canlı mankenler tarafından performe edilmiştir. Fotoğraflar bir defile salonunda dikey olarak fotoğraflanmıştır, arka plan sade, basit ayrıntılar ve dekordan yoksundur. Yürüyüş platformu Barbileştirilmiş canlı mankenler tarafından sunulan giysileri ve marka adını öne çlkaracak biçimde düzenlenmiştir. Mankenler fotoğrafın merkezinde ve giysilerinin canlı renkleri dikkati onların üzerine toplamaktadır.

Fotoğraflardaki giysilerin her biri popüler kültürün bir objesi olan Barbie moda bebeklerinin farklı deneyim alanlarına aittir. Kendiside bir tüketim nesnesi olan Barbie yine bir tüketim unsuru olan modanın seri üretimiyle uyumludur. Bu bağlamda Barbie moda bebekleri kitle kültürünün șekillendirdiği değerlerin bir temsilcisi olarak endüstriyel moda tasarımcılarının batılı giyim sitillerini tüketicilerine benimseten birer rol modeldir. Diğer yandan mankenlerin farklı fiziksel özellikleri sarışın Barbie'ye yapılan eleştirilere bir cevap niteliğindedir.

\section{Görsel 8-9}

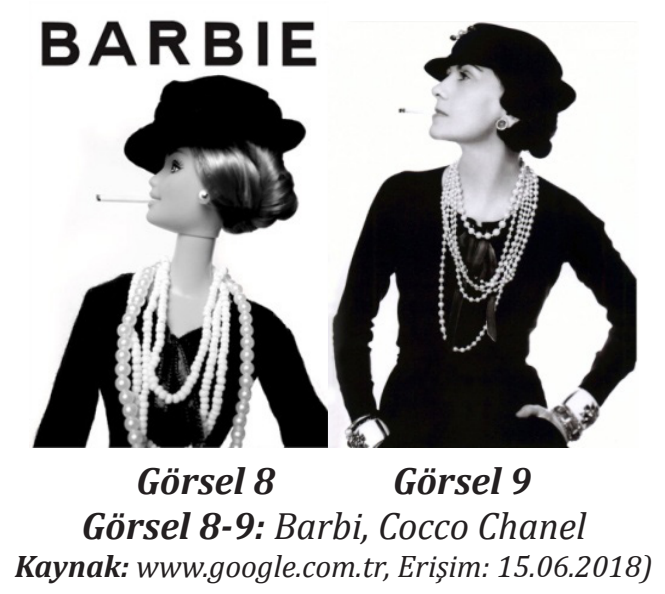

Görsel 8 plastik Barbie bebeğe görsel 9 ise Coco Chanel'e aittir. Fotoğraflar siyahbeyaz, bağlamsızdır ve figürler dikey olarak merkezde yer almaktadır. Fotoğrafta yer alan her iki kadınında bakışları yukarı yönlü ve izleyicisinden uzaktır. Fotoğrafın çekim uzaklığı onları birer birey olarak algılamamızı sağlamaktadır. Barbie yazısıyla etiketlenmiş görsel 8, görsel 9'un yeniden üretimidir.

Coco Chanel kendi tasarımları olan elbise ve şapkası ile fotoğraflanmıștır. Fotoğrafta aksesuar olarak Chanel ile özdeşleşmiş imitasyon inciler göze çarpmaktadır. Ayrıca 
giyim tarzı ve ağzındaki sigara ile erkeğe ait kodları bir özgürlük ifadesi olarak kendi görseline taşımıştır. Coco Chanel modernizmin özgürleştirdiği kadın profilinin bir temsilcisidir. Yenilikçi fikirleri ile çağımıza damgasını vuran bir tasarımcı, modern kadın giyiminin yaratıcısı, bir sitil ikonu ve yaşam tarzıyla bir rol modeldir. Chanel, kadın giyimini yeniden yorumlamış, tasarımlarında sadeliği, pratikliği ve şıklığı bir araya getirmiştir. Ancak Chanel'in toplumsal etkisi yalnızca moda ile sinırlı değildir o aynı zamanda güçlü, özgür, saygın ve modern bir kadındır. Onun taşıdığı bu kıymetli özellikler giyim ve stil yoluyla Barbie bebeğe taşınarak hem modanın öncü ismi olan bu yaratıcı kadına bir saygı hem de kendisi de bir stil ikonu ve rol model olan Barbie'nin moda ile olan yakın ilișkisinin bir göstergesidir.

\section{Sonuç}

Bu çalışma kapsamında hem çocuklar hem de yetişkinler için bir rol model olan ve çok zaman moda ikonu olarak anılan Barbie moda bebeklerin (fashion doll'ün) moda ile olan ilişkisi transmedyal hikâye anlatımı bağlamında değerlendirilmiş, Barbie bebeklerin taşıdığı sembolik anlamlar sosyal göstergebilimsel analiz yöntemi ile çözümlenmiş ve çalışma bulguları betimsel olarak açıklanmıștır. Transmedya hikâye anlatımı her medyanın kendi olanakları ölçüsünde marka ve ürünün hikâyesini çoğaltarak medya platformları arası akışını ifade etmektedir. Bunun kültürel bir akış olduğu ifade edilir.

1959'da fashion doll olarak üretilen Barbie Bebek idealize edilmiş güzelliğinin ve şıklığının yarattığı etki ile bir kültürel ikon olarak kabul edilir. Barbie bebeğin transmedyal analizinde müzeler, fashion showlar gibi kültürel alanların yanı sıra yeni ve geleneksel medyayı etkili kullandığı ve neredeyse tüm mecralarda yer aldığı görülmektedir.

Barbie uygulamalarında transmedya uygulamalarının olmazsa olmazlarından olan interaktiflik özelliğiyle https://play.barbie.com/tr ve daha birçok web sayfasında yer alan "Barbie Fashionstas" gibi interaktif oyunlarla katılımcllara kendi moda zevkini geliștirme ve uygulama olanağı sağlar. Gene transmedyal uygulamaların en belirgin özelliklerinden biri olan hikâyenin devamlılı̆̆ı ve bir içeriğin farklı medya platforlarında anlatılması "Barbie A Fashion Fairy Tale", film ve boyama kitabı uygulamasında gözlenmektedir.

Bir transmedyal uygulama olan marka adının farklı kategorilerden oluşan ve birbiriyle bağlantılı olarak üretilen birçok ürünle yayılması özelliği Barbie transmedya analizinin sonuçlarındandır. Barbie, genellikle pembe ve kendi logosunu taşıyan ürünlerle hem kullanıcılara satış yerlerinden ulaşmakta hem de birçok Barbie film, kitap ve oyunun konusunu oluşturmaktadır. Bu ürünlerin Barbie moda anlayışının ve yaşam tarzının empoze edilmesinde etkili olduğu söylenebilir.

Transmedya anlatım zenginliği sağlar ve hikâye içeriklerinin bir platformdan diğerine akışında farklı anlatım biçimlerine olanak sağlar. $\mathrm{Bu}$ anlatım biçimi yazıll, sözlü, görüntülü olabileceği gibi bir performans da olabilir. Yapılan analizde Barbie'nin bu anlatım zenginliğinden yaralandığ şeklinde değerlendirilmiştir. İkonik birçok markanın moda evlerinin Barbie temalı kreasyonları ve bunların moda showları bir anlatım zenginliği oluşturmaktadır. Yine ünlü oyuncu ve modellerin kendi bedenlerinde Barbie'yi performe ettiği, onun gibi giyinerek poz verdiği analizlerde görülmektedir. Bunun Barbie'nin sitilinin bu kişilerin hayran kitlelerine 
taşınmasında ve marka popülaritesinin artırılmasında etkili olduğu kadar Barbie'nin bir bebek olmanın ötesinde moda dünyasını derinden etkileyen bir rol model olduğu söylenebilir.

\section{Kaynakça}

Akbulut, D. (2009), Günümüzde Geleneksel Oyuncaklar. Millî Folklor, Yıl 21, Sayı 84.

Barthes, R. (2013). The Langage of Fashion. Translated by andy Stafford. Sydney: Bloomsbury Academic.

Best,Kellner (1998).Postmodern Teori.İstanbul:Ayrıntı Yayınları

Cliff, Cameron (2017). Transmedia Storytelling Strategy. Thesiss - The degree of a Doctor of Philosophy, School of Media, Entertainment and Creative Arts Faculty of Creative Industries Queensland University of Technology

Crane, D. (2003). Moda ve Gündemleri.(Ö. Çelik, Çev.) İstanbul: Ayrıntı Yayınları.

Dal, V. ve Gürpınar, M. (2010). Hazır Giyim Sanayinde Hızlı Moda Kavramı ve Bir Model Önerisi. İstanbul: İstanbul Sanayi Odası Yayınları. Yayın No: 2010/13, ISBN: 978-9944-60-734-6 (ELEKTRONIK),

Daynes, K. (2007). Modanın Göz Kamaştıran Hikâyesi. İstanbul: Bilge Kültür Sanat Yayın Dağıtım San. Ve Tic. Ltd. Şti.

Davis, F. (1997). Moda Kültür Ve Kimlik. (Ö.Arıkan, Çev.). İstanbul:,Yapı Kredi yayınları

Dijk,Van Jan (2016). Ağ Toplumu.İstanbul:KAFKA, Epilson Yayıncılık

Dönmez, M. ve Güler, Ş. (2016). Transmedia Storytelling “Doritos Akademi Study Case. Suleyman Demirel University The Journal of Visionary, Volume: 7, Number: 16, pp.155-175

Featherstone (2013).Postmodernizm ve Tüketim Kültürü.3.Basım. İstanbul:Ayrıntı Yayınları

Ferguson, S. (2006). The Children's Culture Industry and Globalization:Shifts in the Commodity Character of Toys. International Symposium "Transformations in the Cultural and Media Industries" September

Fogg, M. (2014). Modanın Tüm Öyküsü. İstanbul:Hayalperest Yanınları

Gürel,Tığlı (2014). New World Created By Socıal Media:Transmedia Storytelling. Journal of Media Critiques [JMC] Special Issue 1 - 2014 P-ISSN: 2056-9785 E-ISSN: 20569793

Hoskins, T. E. (2015). Foya: Modanın Anti-Kapitalist Kitabı. (D. Bayraktaroğlu, Çev.) Ankara: Ütopya Yayınevi

Jenkins, H. (2016). Cesur Yeni Medya. İstanbul: İletişim Yayınları

Jewitt,Carey ve Oyama, Rumiko (2007). Görsel Anlam: Sosyal Göstergebilimsel Bir Yaklaşım. Derleyemn:G.Ş.Atabek, Ümit Atabek.Ankara:Siyasal Kitapevi

Kawamura, Y. (2016). Moda-Loji:Moda Çalışmalarına Giriş. İstanbul: Ayrıntı Yayınları

Mangold, W. G. ve Faulds, D. J. (2009) Social media: The new hybrid element of the promotion mix. Business Horizons 52, 357-365 
Noh, M., Lit, M. Martin, K. ve Purpura, J. (2015). College Men's Fashion: Clothing Preference, İdentity, and Avoidance. Noh et al. Fashion and Textiles 2:27 DOI 10.1186/s40691-015-0052-7

Norton, K. I. Olds, T. S. Olive, S. Dank, S. (1996). Ken And Barbie e At Life Size Sex Roles. Volume 34, Issue 3-4, pp 287-294

Pearson, M. Ve Mullins, P. R. (1999). Domesticating Barbie e: An Archaeology of Barbie e Material Culture and Domestic Ideology. International Journal of Historical Archaeology, Vol.3, No. 4,

Phillips, K. R. (2015). Metinsel Stratejiler, Plastik Taktikler,-Batman ve Barbie e'yi Okumak. (A. K. Cengiz Çev.). folklor/edebiyat, cilt:21, sayı:81

Piche, B. (2009). The Intentions Behind the Creation of Barbie. Constructing the Past: Vol. 10 : Iss. 1 , Article 4. Available at: http://digitalcommons.iwu.edu/ constructing/vol10/iss1/4

Scoları, C. A. a . (2009). Transmedia Storytelling: Implicit Consumers, Narrative Worlds, and Branding in Contemporary Media Production. International Journal of Communication 3 586-606

Scott, L. M. (2002). Barbie e Genesis Play, Dress, and Rebellion Among Her First Owners. in GCB - Gender and Consumer Behavior. Volume 6, eds. Pauline Maclaran, Paris, France : Association for Consumer Research, Pages: 151-165

Simili, I. ve G. Souza, M. C. De .(2015). Girls' beauty according to“Barbie e's tips. Cadernos de Pesquisa v.45 n.155 p.200-217

Simmel, G. (2006). Modern Kültürde Çatışma. (4. Bs.). İstanbul: İletişim Yayınları

Tatar, D. B. (2016). Modernleşmeden Postmodernleșmeye Barbie. Hacettepe HFD. 6(1) 167-192

Toffolettı, K. (2007). Cyborg and Barbie e Dolls. Published by I.B.Tauris \& Co Ltd, New York

Tulunski, H. (2017). Barbie e As Cultural Compass: Embodiment, Representation, and Resistance Surrounding the World's Most Iconized Doll. Sociology Student Scholarship.

Türker, S. H. (2017). Sosyal Medya, Moda ve Tasarım. İstanbul Ticaret Üniversitesi Yayınları , Sempozyum, Kongre Ve Konferans Bildirileri.

Ünal, S. (2014). Göstergebilimsel Açıdan Sembolik Tüketim. Ankara: Detay yayıncılık

Watson L. (2007). Modaya Yön Verenler. İstanbul: İstanbul Moda Akademisi-Güncel Yayıncllık

Waquet D. ve Laporte M. (2011). Moda. (I. I. Ergüden, Çev.). Ankara:Dost Kitapevi Yayınları

Wohlwend K. E. Ve Peppler K. (2013). Young Children Pedagogy And Arts Ways of Seeing- "Designing with Pink Technologies and Barbie e Transmedia. First published by Routledge Taylor \& Francis Group , New York \& London, 2013, Page, 129-145

Yanık (2016).Yeni Medya Nedir Ne Değildir. Uluslararası Sosyal Araştırmalar Dergisi. Cilt: 9. Sayı: 45 


\section{İnternet Kaynağı}

Babacan, Onat (2002). Postmodern Pazarlama Perspektifi. Erişim: 03 Şubat 2017

Balıketli, uzun veminyon Barbie'lergeliyor. Erişim: 01 Şubat2016 http://www.radikal. com.tr/hayat/balik-etli-uzun-ve-minyon-Barbie eler-geliyor-1503161/

Baykal, A . Pazarlamada Hikâye Anlatımı. Erişim: 29 Temmuz 2017 https://www. researchgate.net/publication/283548460_Pazarlamada_Hikâye_Anlatimi

Barbie Blogger oldu. https://vogue.com.tr/haber/barbie-de-blogger-oldu

Barbie'nin 57 Ylllık Tarihi Müzede Sergileniyor. Erişim: 01 Ağustos 2017 http://www. turizmglobal.com/Barbienin-57-yillik-tarihi-muzede-sergileniyor

Barbie Modanın Yeni Öncüsü. http://www.milliyet.com.tr/Barbie-modaninyeni-oncusuoldu/cumartesi/haberdetay/16.11.2013/1792798/default . Erişim:12 Temmuz 2017

Disney'den Hollywood'a Yeni Obsesyon: Bambi Pozu. Erişim: 31 Temmuz 2017 http:// vogue.com.tr/unluler/disneyden-hollywooda-yeni-obsesyon-bambi-pozu

Driessen, R. (2016). The Evolutıon Of An Icon. Erişim: 13 Aralık 2017 http:// theses.ubn.ru.nl/bitstream/handle/123456789/4706/Driessen\%2C\%20 Robin\%204348664.pdf?sequence=1

Güçdemir, Derya.Yeni Medya Yaşamın Her Yerinde: Hikâyede Büyük Boşluklar Var Öyküleriyle Yeni Medya Ortamlarını, Kamusal - Özel Alanı ve Katılımcı Kültürü Düşünmek

https://yenimedya.wordpress.com/2017/01/11/yeni-medya-yasamin-heryerinde, ErişimTarihi:13 Haziran 2018

İnternet Bağlantılı Barbie. Erişim: 27 Şubat 2018 http://her-an.org/2015/03/ internet-baglantili-Barbie/

Introducing Social Semiotics, Erişim: 07 Haziran 2018 https://pdfs.semanticscholar. org/aca7/c8ffa23c38b05faede391273a4130fc28b4a.pdf

Mattel- The Barbie e ${ }^{\circledR}$ Doll Story. Erişim: 29 Temmuz 2017 http://files.shareholder. com/downloads/MAT/0x0x224707/f260e302-5ac6-476b-a28e415c42ffff25/MAT_News_2002_4_28_Barbie e_News.pdf

Osipova M. (2015). Transmedia storytelling in fashion. DOI: 10.13140/ RG.2.2.28672.84487, https://www.researchgate.net/profile/Maria_ Osipova2/publication/307932507_Transmedia_storytelling_in_fashion/ links/57d278fe08ae601b39a3a4ff/Transmedia-storytelling-in-fashion.pdf

Pratten, R. (2011). Getting Started In Transmedia Storytelling: A Practical Guide For Beginners. Erişim: 29 Temmuz 2017 http://videoturundus.ee/transmedia. pdf

The State Of Fashion. Erişim: 29 Temmuz 2017 https://images.businessoffashion. com/site/uploads/2016/11/The_State_of_Fashion_2017.pdf

Thinking Through Fashion. Erişim: 29 Temmuz 2017 http://www.annekesmelik.nl/ wp-content/uploads/2015/08/TTF-INTRODUCTION.pdf

Transmedia Storytelling 101. Erişim: 03 Mart 2018 http://henryjenkins.org/ blog/2007/03/transmedia_storytelling_101.html 
Uncu, G. Popüler Kültür İkonu Olarak “Barbie” Bebek; Toplumsal Cinsiyet Bağlamında Yaratılan Yeni Kadın Imgesi. Erişim: 04 Aralı 2017 https://www.academia. edu/33249712/POPÜLER_KÜLTÜR_İKONU_OLARAK_BARBİE_BEBEK_ TOPLUMSAL_CINSIYYET_BAĞLAMINDA_YENİ_KADIN_İMGESİ

Vogue-Tabu Yıkan Barbie Bebekler . Erişim:12 Temmuz 2017 https://vogue.com.tr/ metropol/tabu-yikan-Barbie-bebekler

Whatis TransmediaStorytelling?.Erişim: 02 Mart2018 https://transmediajournalism. org/contexts/what-is-transmedia-storytelling/

Welcome to convergence culture. Erişim: 27 Şubat 2018 http://henryjenkins.org/ blog/2006/06/welcome_to_convergence_culture.html

Suzy Menkes|Moschino: Barbie goes to Milan. http://www.vogue.it/en/suzymenkes/suzy-menkes/2014/09/moschino-barbie-goes-to-milan?refresh_ ce=\#ad-image. Erişim: 14 Haziran 2018

www.Barbieoyuncakbebek.com . Erişim:12 Temmuz 2017, Saat:10.02

http://www.Barbieoyuncakbebek.com/Barbie-bebeklerin-tarihi.

Erişim:12

Temmuz 2017

http://www.Barbieoyuncakbebek.com/Barbie-moda-seti-djw58. Erişim: 01 Ağustos 2017

Http://www.Barbieoyuncakbebek.com/Kategori/oyuncak-figurler.Erişim:12 Temmuz 2017

http://www.dr.com.tr/Kitap/Barbie-Moda-Masali. Erișim: 01 Ağustos 2017

http://en.vogue.fr/suzy-menkes/suzy-menkes-column. Erişim:12 Temmuz 2017

https://www.google.com.tr/search? . Erişim: 03 Mart 2018

http://www.idefix.com/Film/Barbie-Fashion-Fairytale-Barbie-Moda-Masali.

Erişim: 04 Ağustos 2017

http://www.idefix.com/Film/Barbie-Fashion-Fairytale-Barbie-Moda-Masali. Erişim: 04 Ağustos 2017

http://www.k-note.com.tr/sik-Barbie-bebekler/. Erişim:01 Ağustos 2017

http://www.locopoco.com/urunara?search=true\&srchtxt=elbise.

Erişim:12

Temmuz 2017

https://play.Barbie.com/tr-tr . Erişim:12 Temmuz 2017

https://play.Barbie.com/tr-tr . Erişim:12 Temmuz 2017

https://play.Barbie.com/tr-tr/explore/careers. Erişim:12 Temmuz 2017

https://present.me/view/160433-Barbie-as-a-transmedia-story-j. Erişim: 30 Temmuz 2017

http://www.tdk.gov.tr/index.php?option=com_bts\&arama=kelime\&guid=TDK. GTS.5705f1e25d7756.54452736. Erişim: 01 Şubat 2016

https://urun.gittigidiyor.com/oyuncak/Barbie-yazar-kasa-interaktif-seslimikrofonlu-aksesuarli-318901853. Erişim: 03 Mart 2018 
https://www.google.com.tr/search?q=ünlülerin+barbie+pozu\&rlz=1C1AWFA. Erişim:03 Mart 2018

https://www.google.com.tr/search?q=barbie+ideal\&biw=, Erişim:14.06.2018 